\title{
Sex determination in mammalian germ cells: extrinsic versus intrinsic factors
}

\author{
Josephine Bowles and Peter Koopman \\ Division of Molecular Genetics and Development, and ARC Centre of Excellence in Biotechnology and Development, \\ Institute for Molecular Bioscience, The University of Queensland, Brisbane, Queensland 4072, Australia \\ Correspondence should be addressed to J Bowles; Email: j.bowles@imb.uq.edu.au
}

\begin{abstract}
Mammalian germ cells do not determine their sexual fate based on their XX or XY chromosomal constitution. Instead, sexual fate is dependent on the gonadal environment in which they develop. In a fetal testis, germ cells commit to the spermatogenic programme of development during fetal life, although they do not enter meiosis until puberty. In a fetal ovary, germ cells commit to oogenesis by entering prophase of meiosis I. Although it was believed previously that germ cells are pre-programmed to enter meiosis unless they are actively prevented from doing so, recent results indicate that meiosis is triggered by a signaling molecule, retinoic acid (RA). Meiosis is avoided in the fetal testis because a male-specifically expressed enzyme actively degrades RA during the critical time period. Additional extrinsic factors are likely to influence sexual fate of the germ cells, and in particular, we postulate that an additional male-specific fate-determining factor or factors is involved. The full complement of intrinsic factors that underlie the competence of gonadal germ cells to respond to RA and other extrinsic factors is yet to be defined.

Reproduction (2010) 139 943-958
\end{abstract}

\section{Introduction}

Germ cells are the special cells of the embryo that ultimately give rise to the spermatozoa and oocytes. They are unique in their ability to undergo meiosis, a specialized form of cell division that allows them to halve their genetic material, producing haploid cells. Hence, germ cells are critical for the transfer of genetic material from one generation to the next.

A fundamental question in biology relates to how mammalian germ cell sexual fate is determined - how germ cells come to commit to either spermatogenesis or oogenesis. An answer may seem obvious to the non-specialist - surely XY germ cells will become sperm and XX germ cells will become oocytes. But in mammals, perhaps surprisingly, 'the sex of a germ cell is not an autonomous property but is determined by the nature of the gonad in which it finds itself' (Evans et al. 1977). In other words, whether a germ cell will ultimately form a sperm or an oocyte is not simply a matter of whether it is chromosomally XX or XY. Instead, it seems that the immediate somatic environment acts to push germ cells toward one or other fate (McLaren 1975, 1981, Palmer \& Burgoyne 1991, Adams \& McLaren 2002). So, germ cells of either $X X$ or $X Y$ chromosomal constitution will take the first step toward oogenesis if they find themselves in the environment of a fetal ovary, while $X X$ or $X Y$ germ cells will commit to spermatogenesis if they are placed in the fetal testis (reviewed by McLaren (2003)).
A commitment to oogenesis involves pre-meiotic DNA replication and entry into and progression through prophase of the first meiotic division during fetal life. On the other hand, a commitment to spermatogenesis involves avoidance of meiotic initiation during fetal life, mitotic arrest and the expression of certain cell fate markers that appear to lock in the male programme of development. Although we are making rapid progress in understanding mammalian germ cell sex determination, it is not clear to what extent germ cell sexual fate is governed by intrinsic rather than extrinsic factors. In particular, it is not clear whether both meiosis and mitotic arrest are actively triggered by the ovary and testis respectively, or whether one or both of these fates is pre-programmed and will ensue cell autonomously unless it is actively prevented. Current evidence suggests that, in this system, non-sex-specific intrinsic factors (such as transcription factors and epigenetic state) determine competence to respond to environmentspecific extrinsic factors (such as growth factors and other signaling molecules).

\section{Making, moving, and maturing the germ cells}

In the mouse embryo, germ cells are specified from about 6.25 days post coitum (dpc); from about $8.5 \mathrm{dpc}$, they migrate through the embryo as it forms; and finally, they lodge in the gonad as it is forming at about 
$10.5 \mathrm{dpc}$. At the time of entering the gonads, germ cells are bipotential but over the next few days, under the influence of the gonadal environment, germ cells commit to one or other sexual fate. In this review, therefore, we discuss specification and migration of germ cells as a precursor trying to understand how these cells mature to the point of being competent to commit to one or other sexual fate.

\section{Specification and transcriptional identity of the germ line}

In many species, including Drosophila melanogaster, Danio rerio, and Caenorhabditis elegans, the germ cell lineage is set aside from the somatic lineage very early in development. This is achieved by a system where preformed germ line determinants in 'germ plasm' are inherited from the oocyte. In mammals including the mouse, the model system we focus on here, the germ cell lineage is not pre-determined but is induced by external signals at the egg cylinder stage of development, prior to the onset of gastrulation (Ginsburg et al. 1990, Lawson \& Hage 1994, Tam \& Zhou 1996). The main features of mammalian germ cell specification are summarized in Fig. 1. For reference, a list of genes involved in germ cell development is provided in Table 1. For a more comprehensive overview of the topic, see recent reviews (Surani et al. 2007, Saitou 2009b).

It is thought that bone morphogenetic protein (BMP) signals emanate from the extraembryonic ectoderm (BMP4 and BMP8B) and visceral endoderm (BMP2) as early as $5.5 \mathrm{dpc}$, and that based on a signaling gradient set up as a result, a region permissive for the formation of germ cell precursors arises in the proximal epiblast (Lawson et al. 1999, Ying et al. 2000, Ying \& Zhao 2001, de Sousa Lopes et al. 2004). Competence to respond to the BMP signaling seems to exist only during the 5.5-6.25 dpc period and to be related to expression of Wnt3 (Ohinata et al. 2009). From about $6.25 \mathrm{dpc}$ the cells in this region express Ifitm3, a member of an interferon-inducible gene family and a key marker gene that has nonetheless proven non-essential during primordial germ cell (PGC) formation (Lange et al. 2008). These cells are not founder PGCs, since not all of their living descendants go on to become gametes. A subset of the Ifitm3-positive cells go on to express PRDM1 (also known as BLIMP1) and PRDM14, PR-domain proteins that are transcriptional repressors of a histone methyltransferase subfamily and are considered the key PGC determinants (Ohinata et al. 2005, Saitou et al. 2005, Vincent et al. 2005, Yamaji et al. 2008). Likely functions of PRDM1 in repression of the somatic genes, reactivation of potential pluripotency, induction of germ cell lineage genes, and control of epigenetic reprogramming have been reviewed (Saitou 2009a). PRDM14 does not appear to repress somatic

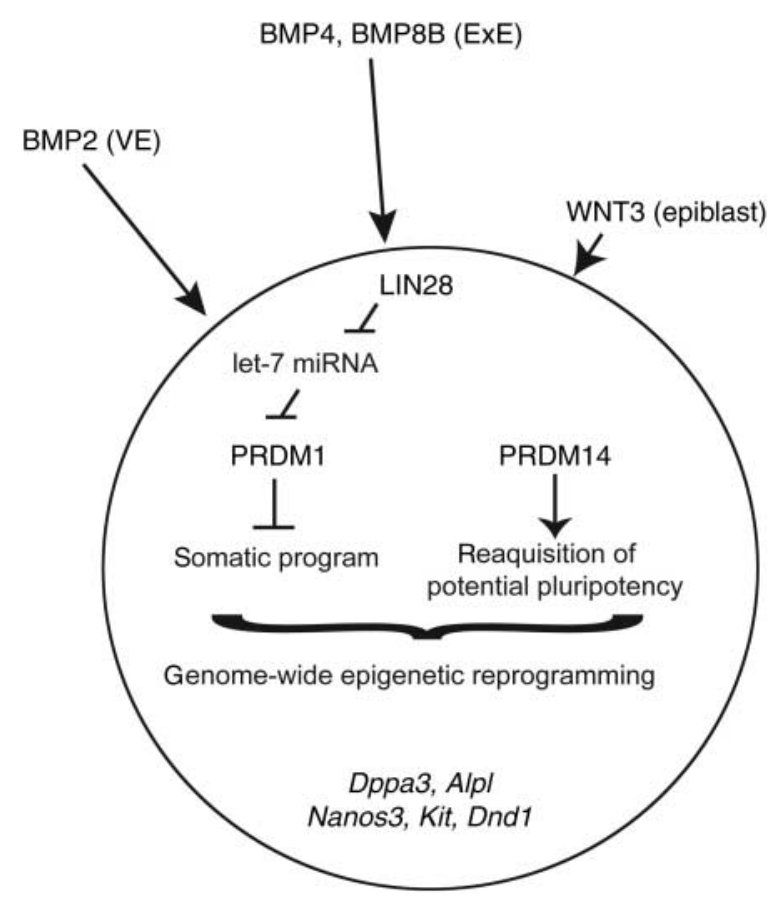

Figure 1 Specification of mouse PGCs. Extrinsic factors BMP4 and BMP8B (from the extraembryonic ectoderm, ExE) and BMP2 (from the visceral endoderm, VE) act on the epiblast to define a region permissive for the formation of PGC precursors. WNT3 appears to make epiblast cells competent to respond to BMPs. Intrinsic factor LIN28 is necessary for Prdm1 expression, and PRDM1 and PRDM14 seem to repress expression of somatic genes and trigger reacquisition of potential pluripotency respectively. Ultimately, germ cell-specific chromatin modifications occur, and expression of definitive PGC marker genes Dppa3 and Alpl, and PGC lineage-specific genes Nanos3, Kit, and Dnd1 is induced.

genes but is necessary for the reactivation of the pluripotency gene Sox2 and for successful epigenetic reprogramming (Yamaji et al. 2008). Expression of $\operatorname{Prdm} 1$ requires the presence of the RNA-binding protein LIN28, which inhibits maturation of Prdm1-repressive microRNA (miRNA) let-7 family members (West et al. 2009). It is believed that PRDM1 represses the somatic mesodermal programme, plays a role in the induction of germ cell lineage genes, and triggers genome-wide epigenetic reprogramming. By $7.25 \mathrm{dpc}$, about 40 cells expressing Dppa3 and Alpl are considered to represent the founder PGC population (Saitou et al. 2002, Hayashi et al. 2007). Despite their status as markers of the germ cell lineage, neither Dppa3 nor Alpl are necessary for germ cell specification (MacGregor et al. 1995, Bortvin et al. 2004).

The pluripotency-associated genes Pou5f1 and Nanog continue to be expressed in the PGC precursors and PGCs, but are downregulated in the surrounding somatic cells from about $6.75 \mathrm{dpc}$. Expression of the third member of the 'core pluripotency regulatory complex', Sox2, is detected in the PGC precursors only 
Table 1 Symbols, names and common aliases for genes involved in mouse germ cell development and differentiation.

\begin{tabular}{|c|c|c|}
\hline Gene symbol & Gene name & Common aliases \\
\hline Alpl & Alkaline phosphatase, liver/bone/kidney & Akp2, Tnap \\
\hline Bax & BCL2-associated X protein & \\
\hline$C d k n 1 b$ & Cyclin-dependent kinase inhibitor 1B & p27, p27Kip1 \\
\hline$C d k n 2 b$ & Cyclin-dependent kinase inhibitor 2B & $p 15, p 15 I N K 4 b$ \\
\hline Сур26b1 & Cytochrome P450, family 26, subfamily b, polypeptide 1 & P450RAl-2 \\
\hline Dazl & Deleted in azoospermia-like & Dazla \\
\hline$D d x 4$ & DEAD (Asp-Glu-Ala-Asp) box polypeptide 4 & Mvh (mouse homolog of vasa Drosophila) \\
\hline Dmc1 & $\begin{array}{l}\text { DMC1 dosage suppressor of mck } 1 \text { homolog, meiosis-specific } \\
\text { homologous recombination (yeast) }\end{array}$ & Dmc1h \\
\hline Dnd1 & Dead end homolog 1, zebrafish & \\
\hline Dnmt3l & DNA (cytosine-5-)-methyltransferase 3-like & \\
\hline Dрра3 & Developmental pluripotency-associated 3 & Stella, PGC7 \\
\hline Evx1 & Even-skipped homeotic gene 1 homolog & \\
\hline Fgf8 & Fibroblast growth factor 8 & \\
\hline Fut4 & Fucosyltransferase 4 & Ssea-1, stage specific mouse embryonic antigen \\
\hline Hoxb1 & Homeobox B1 & \\
\hline Ifitm3 & Interferon-induced transmembrane protein 3 & fragilis \\
\hline Kit & Kit oncogene & $c$-kit \\
\hline Myc & Myelocytomatosis oncogene & $c-m y c$ \\
\hline Nanog & Nanog homeobox & \\
\hline Nanos3 & Nanos homolog 3, Drosophila & \\
\hline Pou5f1 & POU domain, class5, transcription factor 1 & Oct4, Oct3/4 \\
\hline $\operatorname{Prdm} 1$ & PR domain-containing 1, with ZNF domain & Blimp1 \\
\hline $\operatorname{Prdm} 14$ & PR domain-containing 14 & \\
\hline Rarb & Retinoic acid receptor $\beta$ & \\
\hline Rb1 & Retinoblastoma 1 & $R b$ \\
\hline Snai1 & Snail homolog 1 (Drosophila) & Snail \\
\hline Sox2 & Sry-box containing gene 2 & \\
\hline Sry & Sex determining region of chromosome $\mathrm{Y}$ & \\
\hline Stra8 & Stimulated by retinoic acid gene 8 & \\
\hline Sуср3 & Synaptonemal complex protein 3 & Scp3, Cor1 \\
\hline$T$ & Brachyury & \\
\hline Tdrd1 & Tudor domain-containing 1 & \\
\hline Trp53 & Transformation-related protein 53 & p53 \\
\hline Trp63 & Transformation-related protein 63 & p63 \\
\hline Wnt3 & Wingless-related MMTV integration site 3 & \\
\hline Wnt5a & Wingless-related MMTV integration site $5 \mathrm{~A}$ & \\
\hline
\end{tabular}

from about $6.25 \mathrm{dpc}$. The specific expression of Sox 2 at this time completes the pluripotency triad and may mark the time of re-acquisition of pluripotency in this lineage (Yabuta et al. 2006).

Germ line-specific markers Nanos3 and Dnd1 are first expressed in PGCs around 7.25 dpc (Yabuta et al. 2006). Nanos3 encodes an evolutionarily conserved RNAbinding protein and is essential for germ cell survival due to a role in suppressing apoptosis (Tsuda et al. 2003, Suzuki \& Saga 2008). Dnd1 encodes the mouse ortholog of the zebrafish RNA-binding protein Dead end that acts to displace miRNAs from $3^{\prime}$-UTRs of mRNAs, thus preventing miRNA-mediated repression (Kedde et al. 2007). A natural mouse mutation of Dnd1 (Ter mutation) exists: a single base change introduces a stop codon in the coding region of the gene (Stevens 1973, Youngren et al. 2005). Most Ter germ cells are removed by apoptosis during the migratory period, and DND1 seems to be involved in maintaining germ line specificity and preventing germ cells becoming tumorigenic (Youngren et al. 2005, Cook et al. 2009). Although Dead end is necessary for germ cell migration in fish (Weidinger et al. 2003), the few remaining germ cells in Ter mice do reach the genital ridge (Youngren et al. 2005): this discrepancy suggests the possibility that the Ter mutant of Dnd1 retains some function.

Kit, encoding the KIT tyrosine kinase receptor, is specifically upregulated in PGCs at $7.25 \mathrm{dpc}$ (Yabuta et al. 2006). Homeobox genes are downregulated in PGC precursors starting with homeobox B1 (Hoxb1) at $6.75 \mathrm{dpc}$ (Saitou et al. 2002). Posterior mesoderm markers Evx1, T, Fgf8, and Wnt5a as well as the epithelial to mesenchymal transition marker gene Snai1 and the cell proliferation marker Myc are downregulated in PGCs from 7.25 dpc (Yabuta et al. 2006). Transcriptional profiling of genes involved in cellular signal transduction pathways indicates that PGCs are likely to decrease in sensitivity to BMP signaling and increase in sensitivity to transforming growth factor- $\beta$ signaling between 7.25 and $7.75 \mathrm{dpc}$ (Yabuta et al. 2006).

From $8.0 \mathrm{dpc}$, a transient loss of the maintenance DNA methyltransferase DNMT1 and the de novo methyltransferases DNMT3A and DNMT3B from germ cell nuclei occurs, followed by rapid erasure of 
DNA methylation and reduction of repressive $\mathrm{H} 3 \mathrm{~K} 9$ dimethylation specifically in germ cells (Seki et al. 2005). At about $8.75 \mathrm{dpc}$, there is a large increase in repressive $\mathrm{H} 3 \mathrm{~K} 27$ trimethylation, a mark generally associated with pluripotent cell lineages and which in this case may be associated with reacquisition of totipotency (Seki et al. 2005).

An important point with respect to specification of the germ cells lineage is that no cells of the epiblast are pre-determined as PGC precursors. Cells from any part of the epiblast can be induced to give rise to PGCs if present in the correct location and at the correct time for signals to be received (Tam \& Zhou 1996). Thus, all of the transcriptional and epigenetic changes necessary for the generation of the germ cell lineage are triggered by extrinsic signals from somatic cells.

\section{Migration of the PGCs}

By $7.5-8.5 \mathrm{dpc}$, the PGCs are proliferating rapidly and begin to migrate as a group from the base of the allantois, through the posterior primitive streak and into the developing hindgut. It is not clear how this mesoderm to endoderm migration is initiated; IFITM1, a member of the IFITM family of cell surface proteins was implicated (Tanaka et al. 2005); however, deletion of the entire IFITM gene family did not result in PGC migration defects (Lange et al. 2008). From about $10.5 \mathrm{dpc}$, the PGCs move into the midline dorsal body wall and then laterally into the genital ridges, the precursors of the gonads (Yeom et al. 1996, Molyneaux et al. 2001). It is believed that PGC migration is directed by somatic cellproduced chemoattractants including the chemokine stromal-derived factor 1 (SDF1; CXCL12; Ara et al. 2003) and the growth factor kit ligand KITL (SCF, steel factor; Mahakali Zama et al. 2005). Corresponding receptors CXCL4 and C-KIT (KIT oncoprotein) are expressed by the PGCs (Molyneaux et al. 2001, 2003, Stebler et al. 2004, Farini et al. 2007). The adherens junction component E-cadherin and $\beta 1$-integrin, expressed by PGCs as they migrate out of the hindgut, are necessary for their colonization of the genital ridges; E-cadherin is responsible for germ cell-germ cell interactions, while $\beta 1$-integrin is likely to facilitate interactions of germ cells with the extracellular matrix (Anderson et al. 1999, Bendel-Stenzel et al. 2000, Di Carlo \& De Felici 2000). SDF1 and KITL are thought to act also as survival factors during migration (Wylie 1999, Molyneaux et al. 2003, Runyan et al. 2006). Since the same factors seem to be involved in directing migration and promoting survival, it has proved difficult to dissect the specific in vivo roles of the various factors involved. Fibroblast growth factor (FGF) and BMP signaling molecules are thought to be involved in migration, survival, and proliferation (Takeuchi et al. 2005, Dudley et al. 2007). A lipid-based system is thought to guide PGC migration in flies (reviewed by Richardson \&
Lehmann (2010)), and there is evidence for a role of both isoprenoids and cholesterol in PGC migration in vertebrates (Thorpe et al. 2004, Ding et al. 2008).

It has been noted that pro-apoptotic genes are upregulated in germ cells during their migration (Runyan et al. 2006). Possibly germ cells at this stage are programmed to die in the absence of survival factors. Any PGCs that do not move in to the genital ridges but remain in the midline normally die by apoptosis, because midline somatic cells downregulate expression of KITL, which is presumably acting as a survival factor, between 9.5 and 10.5 dpc (Runyan et al. 2006). A small proportion of the migrating PGCs lodge in the nearby adrenal and are not removed by apoptosis, so presumably, their survival is supported in that environment.

During their migration, it is likely that PGCs are exposed to the signaling molecule retinoic acid (RA), which is widely produced in the embryo (Rossant et al. 1991). However, RA does not induce germ cells to enter meiosis during migration. It is likely that germ cells do not become competent to respond to RA until after their entry into the gonad, or into a similar tissue, such as the adrenal (as discussed below).

\section{Bipotential germ cells in the genital ridges}

The genital ridges develop along the medial surface of each of the mesonephroi, two temporary nephric organs that lie either side of the dorsal mesentery. Arising about $10.0 \mathrm{dpc}$, they are initially bipotential but, at about $10.5 \mathrm{dpc}$ and under the influence of the Y-linked gene Sry, the $\mathrm{XY}$ genital ridges begin to develop as testes and, in the absence of SRY, the $X X$ genital ridges begin to develop as ovaries (Koopman et al. 1991). SRY is expressed in cells of the pre-supporting lineage that then begins to differentiate into Sertoli cells; in the absence of appropriate expression of SRY, pre-supporting cells develop as granulosa cells. Once specified, Sertoli cells drive the male-specific development of other cell types of the testis (Palmer \& Burgoyne 1991). Steroidogenic cells of the developing gonad are initially bipotential; in a testis they are triggered to develop as Leydig cells, while in the ovary they become theca cells. A malespecific migration of mesonephric cells, particularly endothelial cells, into the developing testis contributes to formation of the testis cords that eventually enclose the germ cells (Cool et al. 2008, Combes et al. 2009). Various observations indicate that the male and female somatic pathways of development are finely balanced in the mouse gonad and that, if SRY is not expressed early enough or at high enough levels, it is unable to overcome the default pathway of ovarian development (Eicher et al. 1982, Washburn et al. 2001, Albrecht et al. 2003, Bullejos \& Koopman 2005, Wilhelm et al. 2009). It is into this dynamic environment of a bipotential primordial organ reorganizing as either a testis or an ovary that the germ cells arrive. 


\section{Changes in morphology and expression profile}

As the germ cells enter the genital ridge, major morphological and biological changes are observed, irrespective of whether germ cells are $X X$ or $X Y$ in chromosomal constitution. Post-migratory germ cells are less motile and less invasive when placed in culture, compared with migratory germ cells (Donovan et al. 1986). Moreover, germ cells isolated at $12.5 \mathrm{dpc}$ from the gonads have lost the ability to migrate to the gonads when transplanted back into $10.5 \mathrm{dpc}$ embryo slice cultures (Molyneaux et al. 2004). There is also some loss of potency associated with entry into the gonad; this is evidenced by that fact that it becomes progressively more difficult to generate embryonic germ cell (EGC) lines at this stage (Labosky et al. 1994, Tada et al. 1998).

There are also many changes in gene and protein expression as germ cells enter the gonad (Fig. 2). In particular, the germ cell nuclear antigen GCNA1 is first expressed at this time (Enders \& May 1994). Two key germ cell lineage genes that are expressed only after entry into the gonadal ridge are $D d x 4$ and Dazl. $D d x 4$ encodes a PGC-specific RNA helicase (Tanaka et al. 2000, Toyooka et al. 2000), while Dazl encodes a cytoplasmic RNA-binding protein (Seligman \& Page 1998, Lin \& Page 2005). GCNA1, DAZL and DDX4 are discussed in more detail below. In contrast, some PGC

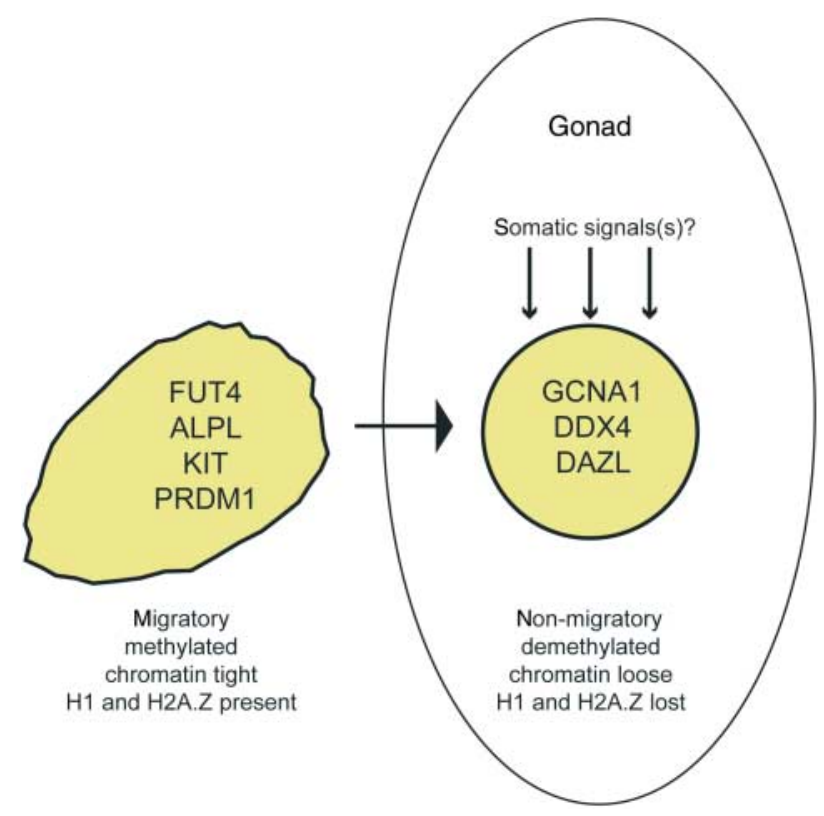

Figure 2 Intrinsic changes observed in germ cells upon colonization of the gonad. When germ cells enter the gonadal environment (at about 10.5-11.5 dpc), PGC markers such as FUT4, ALPL, KIT, and PRDM1 are lost or downregulated, while germ cell markers GCNA1, DDX4, and DAZL are expressed for the first time. Germ cells lose migratory characteristics and genome-wide demethylation, and transient chromatin loosening is observed. Histone variants $\mathrm{H} 1$ and $\mathrm{H} 2 \mathrm{~A} . \mathrm{Z}$ are lost. It is not known whether these changes are induced by signals from the gonadal soma or whether they arise cell autonomously. markers, including Fut4 (Ssea-1), Akpl (Tnap), Kit, and $\operatorname{Prdm1}$, decline or disappear upon entry into the gonad (Maatouk \& Resnick 2003).

Sycp3 and Dmc1, genes associated with meiosis, are slightly upregulated in XX and $\mathrm{XY}$ germ cells upon entry into the gonad, and some SYCP3 protein aggregates are seen in $\mathrm{XY}$ as well as in XX germ cells at $13.5 \mathrm{dpc}$ (Di Carlo et al. 2000, Chuma \& Nakatsuji 2001). These observations suggest that germ cells newly resident in the gonad 'prime' for a possible entry into meiosis. Although this has been interpreted as meaning that germ cells are at this stage on the brink of a cell-autonomous entry into meiosis timed by an internal clock mechanism (Donovan et al. 1986, Ohkubo et al. 1996, McLaren \& Southee 1997), sex-independent signals from the gonadal somatic cells - or similar somatic cells in ectopic locations such as the adrenal (Upadhyay \& Zamboni 1982) - may trigger these expression changes.

\section{Global demethylation and chromatin remodeling}

Upon entry into the gonad, germ cells also undergo remarkable changes in genome methylation status and chromatin architecture. Some of these changes are persistent, while others are transient. Before entry into the gonads, germ cells are already hypomethylated when compared with somatic cells (Seki et al. 2005), but upon entry, they undergo the most widespread and complete demethylation event known during development. Both $X X$ and $X Y$ germ cells undergo genome-wide erasure of existing methylation at imprinted and non-imprinted single copy sequences and some repetitive elements (Monk et al. 1987, Szabo \& Mann 1995, Hajkova et al. 2002, Lee et al. 2002, Sato et al. 2003). The demethylation is rapid and probably active rather than passive. Moreover, the effect is persistent as remethylation does not occur until later during fetal life when $X Y$ germ cells have committed to the spermatogenic fate or, for each XX germ cell, just prior to ovulation. Reactivation of the inactive $X$ chromosome in $X X$ germ cells occurs upon entering the genital ridge (Monk \& McLaren 1981, Tam et al. 1994), although it has recently been reported that this process may begin earlier, at $7.0 \mathrm{dpc}$ in nascent PGCs (Sugimoto \& Abe 2007).

Probably in response to these massive changes in methylation, major changes in chromatin architecture are also observed. At $11.5 \mathrm{dpc}$, germ cell nuclei swell and lose chromocentres, suggesting that the gonadal germ cells have taken on a looser chromatin organization. Heterochromatin relocates toward the nuclear periphery, and some repressive histone modifications (such as H3K27me3 and H3K9me3) are lost, while some marks associated with permissive or active chromatin (H3K4me and H3K9ac) are gained. These changes are likely to correspond to the distinctive 'pre-leptotene' morphology that has been described for $X X$ and $X Y$ germ cells resident in the gonad and at the completion of 
their final mitotic division (Hilscher et al. 1974, McLaren 1984, 2003, McLaren \& Southee 1997). Remarkably, these changes are transient, and are no longer observed at $12.5 \mathrm{dpc}$ (Seki et al. 2005, Hajkova et al. 2008). This temporary alteration suggests the intriguing possibility that a window of competence exists at this critical time in germ cell biology. Chromatin modifications that persist in the germ cells are also observed, including the loss of histone variants $\mathrm{H} 1$ and $\mathrm{H} 2 \mathrm{~A} . \mathrm{Z}$ (Hajkova et al. 2008). It is likely that these changes are triggered by signals from gonadal somatic cells, but the nature of such signals is not yet known, and it remains possible that the changes arise cell autonomously.

\section{Sex determination in the germ line}

Upon entry into the genital ridges, the bipotential germ cells still continue to divide mitotically for 2-3 days. At about 12.5-13.5 dpc, germ cells in a developing ovary cease mitosis and enter prophase of the first meiotic division, thereby committing to the female programme of development. They progress through the various stages of leptonema, zygonema, pachynema, and diplonema until they reach dictyate arrest at around the time of birth (Monk \& McLaren 1981, Speed 1982). The oocytes remain in this arrested state until just before ovulation when they complete the first meiotic division, begin the second, and arrest again. Meiosis is completed only after fertilization.

Germ cells in a developing testis do not enter meiosis during fetal life but instead arrest in $G_{0} / G_{1}$ phase of the cell cycle at about 12.5-13.5 dpc (Hilscher et al. 1974, McLaren 1984). The germ cells (or 'gonocytes') remain in this quiescent state until after birth when they resume proliferation, and some migrate to the peripheral basement membrane of the seminiferous tubules of the testis. They transform into germ line stem cells (spermatogonial stem cells) that can both self-renew and produce daughter cells that differentiate into spermatozoa. Daughter spermatogonia enter meiosis beginning at around 5 days post natum and complete both meiotic divisions to produce haploid cells known as spermatids. Spermatids differentiate and mature further to eventually produce functional gametes, the spermatozoa.

Sex determination in the germ line, therefore, comes down to the choice between entering meiosis, and thereby locking in a female fate, versus avoiding meiosis, entering mitotic arrest and locking in a male fate.

\section{Choosing meiosis: do germ cells jump or are they pushed?}

Although it is well accepted that the fetal testis produces a factor or factors to ensure that germ cells do not enter meiosis, there has been considerable uncertainty as to whether germ cells spontaneously enter meiotic prophase or whether they are induced to do so by the surrounding tissue. Over several decades, evidence supporting both propositions has been presented (Bowles \& Koopman 2007). Briefly, active induction of meiosis is supported by evidence that an influence from the adjacent mesonephric tissue is necessary (Byskov 1974, Byskov \& Saxen 1976) and also by recent studies implicating the signaling molecule RA, discussed below. Evidence that germ cells are not triggered to enter meiosis, but that they do so cell autonomously, includes the observation that ectopic germ cells in the adrenal tend to enter meiosis (Upadhyay \& Zamboni 1982, Zamboni \& Upadhyay 1983, Francavilla \& Zamboni 1985, Runyan et al. 2008), as do isolated germ cells in culture (Chuma \& Nakatsuji 2001, Farini et al. 2005) or in co-culture with embryonic lung cells (McLaren \& Southee 1997).

It is now clear that meiosis is induced. In particular, it appears that the signaling molecule RA is responsible for inducing meiosis in the developing mouse ovary and that meiosis in the developing mouse testis is avoided at least largely because of the RA-degrading action of a P450 enzyme, CYP26B1 (Baltus et al. 2006, Bowles et al. 2006, Koubova et al. 2006, MacLean et al. 2007, Anderson et al. 2008). Cyp26b1 is initially expressed in developing mouse gonads of both sexes, but is then greatly upregulated in the testis and downregulated in the ovary (Menke \& Page 2002, Bowles et al. 2006, Koubova et al. 2006). Treatment of fetal testes with RA (or RA agonists) in culture induces expression of the pre-meiotic marker Stra8 (Bowles et al. 2006, Koubova et al. 2006, Trautmann et al. 2008), and upregulation of meiotic markers Sycp3 and Dmc1 (Bowles et al. 2006). Moreover, in two independent Cyp26b1 knockout (KO) mouse models, XY embryos form an apparently normal testis, but RA levels are raised, the pre-meiotic marker Stra 8 and the meiotic marker Sycp3 are greatly upregulated, and XY germ cells enter and progress through meiosis (Bowles et al. 2006, MacLean et al. 2007). Hence, if RA that is endogenously present in the developing gonad is not degraded, $X Y$ germ cells in a testis are induced to enter meiosis. These meiotic $X Y$ germ cells undergo apoptosis by birth, as would be expected given evidence that the testis somatic environment is hostile to meiotic germ cells (O \& Baker 1976, Vigier et al. 1987). These results indicate that CYP26B1 is a male-specific meiosis-preventing factor.

Although $X Y$ germ cells enter meiosis very convincingly in the Cyp26b1 KO, it is possible that other factors, in addition to the absence of RA, contribute to the avoidance of meiosis in the testis. One clue that this may be the case comes from mouse gonad ex vivo organ culture studies, where it is reported that some $X Y$ germ cells, located at a particular end of the gonad, do enter meiosis if all cellular secretion is blocked (Best et al. 2008). This result would suggest that testicular somatic cells secrete a factor that at least helps germ cells avoid entry into meiosis. Another clue comes from very recent 
work showing that epigenetic modification, particularly histone deacetylation, may play some role in the avoidance of entry into meiosis (Wang \& Tilly 2010).

So RA can trigger germ cells, including those resident in a developing testis, to enter meiosis, but is RA required for germ cells to enter meiosis? In ex vivo culture studies, chemical inhibition of RA receptor (RAR) function in embryonic ovaries leads to inhibition of expression of Stra8 and of entry into meiosis (Bowles et al. 2006, Koubova et al. 2006). A recent study using a variation of the vitamin A-deficient (VAD) rat model (late VAD) is enlightening on this point also. RA is a metabolite of vitamin $A$, so in VAD rats, endogenous levels of $R A$ would be expected to be low. In 'late VAD' fetal ovaries, germ cells form and migrate, and gonadal numbers are normal; however, most fail to enter meiosis and remain in an undifferentiated state (Li \& Clagett-Dame 2009). This study therefore complements the mouse $\mathrm{KO}$ studies (Bowles et al. 2006, MacLean et al. 2007); the mouse work demonstrated that RA alone can induce meiosis in competent germ cells, while the rat study demonstrates that, in vivo, vitamin A (the precursor of RA) is required for the normal onset of meiosis in ovarian germ cells.

The key role of STRA8 as a gatekeeper for meiosis initiation was demonstrated by analysis of Stra8 KO mice. In XX Stra8 KO mice, there is no evidence whatsoever that germ cells have entered meiosis since there are no leptotene, zygotene, or pachytene chromosomal configurations and no REC8 or SYCP3 protein loaded onto chromosomes (Baltus et al. 2006). It seems that, in the male mouse, postnatal entry into meiosis also requires RA and Stra8 expression (Baltus et al. 2006, Anderson et al. 2008), although some contention remains (Mark et al. 2008). It is reported that, in Stra8-deficient males, spermatogenesis ceases at the preleptotene/leptotene spermatocyte stage, and that cells then undergo apoptosis (Baltus et al. 2006, Anderson et al. 2008). In another study, in which the mutation was studied on a mixed background, it was reported that there is pre-meiotic DNA replication, partial condensation of chromosomes, and initiation of meiotic recombination, although there is no progress through the leptotene stage of prophase I (Mark et al. 2008). Evidence that both RA and STRA8 are involved in initiating meiosis in both sexes suggests that the molecular control of pre-meiosis S-phase entry is conserved and gender-neutral.

\section{How does RA work its magic?}

$\mathrm{RA}$ is a key molecule in developmental biology, regulating various events in cellular growth and differentiation (Duester 2008, Mark et al. 2009). In particular, RA is a known differentiation factor, particularly with respect to stem cells (Soprano et al. 2007). Although RA is generally widespread in the embryo during development, levels of RA are strictly regulated in a spatiotemporal manner by the balanced actions of synthesis and catabolism enzymes. RA acts through RARs, of which there are many, to modify gene expression in a target cell. It is true that RAR KO mice do not show any defects in ovarian histology, but this is likely to be due to compensation by remaining RARs (Mark et al. 2009). The idea of likely redundancy correlates well with the finding that agonists of each of the three RARs $(\alpha, \beta$, and $\gamma)$ induce Stra8 expression in cultured fetal testes (Koubova et al. 2006).

In the context of mouse germ cells, RA has previously been shown to act as a potent proliferation factor (Koshimizu et al. 1995, Morita \& Tilly 1999). In the mouse gonad, RA seems to act by inducing expression of Stra8 (Bowles et al. 2006, Koubova et al. 2006), a gene considered to be a pre-meiotic marker (Menke et al. 2003), although this point needs to be explored further. Since germ cells in the gonad express RARs (Dolle et al. 1990, Cupp et al. 1999, Bowles et al. 2006) and the Stra8 promoter has two putative RA-response element sequences (Koubova et al. 2006), RA may act directly on germ cells to bring about Stra8 expression. Stra8 was first identified as a RA-responsive gene in P19 embryonic carcinoma (EC) cells (Bouillet et al. 1995). Like Rarb (a classical RA-response gene), Stra8 is considered a type II immediate early response gene. The STRA8 protein was originally described as cytoplasmic in P19 EC cells (Oulad-Abdelghani et al. 1996), but recent evidence suggests that it shuttles between nucleus and cytoplasm, and may bind DNA (Tedesco et al. 2009). Differentially phosphorylated forms have been demonstrated but any significance of these has not been shown (Oulad-Abdelghani et al. 1996). The STRA8 protein has little homology with known proteins making elucidation of its mechanism of action difficult.

It is believed that RA flows or diffuses into the genital ridges from the adjacent mesonephric tubules (also known as the extraovarian rete; Bowles et al. 2006). In accord with this theory, the first known molecular evidence that $X X$ and $X Y$ germ cells are diverging in their developmental paths is the expression of the pre-meiotic marker Stra8 in germ cells resident in the anterior end of the ovary, beginning at about $12.5 \mathrm{dpc}$ (Menke et al. 2003, Koubova et al. 2006). In parallel with an anterior-to-posterior wave of Stra8 expression, anteriorto-posterior waves of meiotic marker (Sycp3, Dmc1, $\mathrm{H} 2 \mathrm{AX}$, and SYN/COR) upregulation and Pou5f1 downregulation have been described (Menke et al. 2003, Yao et al. 2003, Bullejos \& Koopman 2004). Interestingly, at about $14.5 \mathrm{dpc}$, a small population of meiotic germ cells are present transiently at the anterior end of the testis in the gonad/mesonephros junction area (McLaren 1984, Yao et al. 2003). These are removed by apoptosis by $15.5 \mathrm{dpc}$, but presumably they arise because there is some exposure to RA in this area. Although these observations tie RA presence and Stra8 expression to the initiation of meiosis, we still do not know how STRA8 
engages the meiotic machinery. The results of various studies indicate that STRA8 is necessary but not sufficient to push cells into meiosis, so presumably STRA8 protein works to induce meiosis only in the context of cells in a competent state (as discussed below).

Stra8 is found only in vertebrates (Baltus et al. 2006), so any RA-triggered meiosis is likely to be confined at least to that group. Evidence is mounting that RA may trigger entry into meiosis not just in mouse and rat, as detailed above, but also in chickens (Smith et al. 2008) and amphibians (Wallacides et al. 2009). Although a role for RA in initiating meiosis in humans has not been demonstrated so far, an anterior site of meiosis initiation - originating near the rete ovarii which connects the gonad and mesonephros - is observed in many mammalian species including humans (Byskov 1975, Bendsen et al. 2006).

\section{Choosing meiosis in an ectopic context}

One of the main pieces of evidence that has been used to support the theory that germ cells are endogenously programmed to enter meiosis, and do not need to be triggered, comes from examination of rare ectopic germ cells in the mouse. Germ cells that do not colonize the gonads, but instead lodge in the nearby adrenal glands or mesonephros, tend to enter meiosis at much the same time as those in the developing ovary (Upadhyay \& Zamboni 1982, Zamboni \& Upadhyay 1983, McLaren 1984, Francavilla \& Zamboni 1985), although some in the mesonephros developed as T-spermatogonia (McLaren 1984).

A recent study, using Bax-null mice (in which apoptosis is suppressed to some extent), confirmed that germ cells in the adrenal gland do indeed enter meiosis (Runyan et al. 2008). Specifically, these germ cells downregulate early germ cell markers (FUT4 and POU5F1), begin to express DDX4, and upregulate the meiotic marker SYCP3. The newer study shows also that ectopic germ cells in other locations are heterogeneous in their propensity to enter meiosis or to remain undifferentiated (Runyan et al. 2008). In general, other than in the adrenal and peri-gonadal locations, POU5F1 and FUT4 remain on longer in ectopic germ cells than those resident in the fetal ovary, and activation of DDX4 and SYCP3 is delayed. Germ cells that migrated to more cranial locations in the embryo seemed more likely to enter meiosis. A population that seems to be spared from entry into meiosis was located in the tail region where the gene encoding CYP26A1 is expressed; hence, it may be that those germ cells do not enter meiosis because of the absence of RA in that area (Runyan et al. 2008).

Whether ectopic germ cells, in vivo, enter meiosis or not seems to correlate with whether they do or do not 'see' the inducing factor RA. They seem particularly prone to enter meiosis if they colonize the adrenal cortex where RA is known to be present (Haselbeck et al. 1997,
Haselbeck \& Duester 1998). This suggests that germ cells at this time, whether or not they have entered the gonad, are competent not only to respond to RA by upregulating Stra8, but also to enter meiosis. Overall, the heterogeneity observed among ectopic germ cells studied in vivo confirms that germ cell sexual fate is very much dependent on signals from the soma. The status of ectopic germ cells is presumably dictated by the combination of all extrinsic signals encountered in a particular location. One such signal is RA, but it is possible that the other as yet unidentified signaling molecules also have some bearing on germ cell differentiation.

PGCs and germ cells, isolated from mesenteries or gonadal ridges respectively, can enter meiosis when cultured in vitro (Chuma \& Nakatsuji 2001, Farini et al. 2005). In these experiments, cultures were carried out using feeder cells, serum-containing media, and additives necessary to maintain proliferation and to prevent apoptosis. It is possible that RA, and indeed other factors that were present in the system, influenced development and differentiation of the cells. We find that as little as $1 \times 10^{-8} \mathrm{M} \mathrm{RA}$ is sufficient to trigger isolated $11.5 \mathrm{dpc}$ germ cells to express Stra8 (J Bowles \& P Koopman, unpublished data), while media supplemented with $10 \%$ fetal bovine serum has been estimated to contain $3.6 \times 10^{-8} \mathrm{M} \mathrm{RA}$ (Fuchs \& Green 1981).

$X Y$ germ cell meiosis was also observed when $X Y$ urogenital ridges were dissociated and reassociated, leading to a theory that the meiosis-preventing factor is active only in an intact gonadal structure (McLaren \& Southee 1997). The interpretation of this classic experiment is confounded now that the role of RA is known, since RA-producing mesonephric cells would have been included in the reaggregation cultures. Similarly, dissociation and reaggregation of germ cells with lung tissue was found to allow germ cells to progress into meiosis (McLaren \& Southee 1997) - this may reflect the fact that $\mathrm{RA}$ is present in embryonic lung tissue (Malpel et al. 2000).

\section{If not meiosis, then what?}

Germ cells in the developing testis do not enter meiosis but instead stop proliferating, enter $\mathrm{G}_{0} / \mathrm{G}_{1}$ arrest, and commit to the spermatogenic pathway (Hilscher et al. 1974, McLaren 1984, Adams \& McLaren 2002, Western et al. 2008). It is not clear whether the events of mitotic arrest and commitment to spermatogenesis occur cell autonomously in the absence of entry into meiosis, or whether they are triggered by extrinsic signals from the testicular soma.

It has been postulated that cessation of proliferation results from a cell-intrinsic programme regulated stochastically (McLaren 1984, Ohkubo et al. 1996). More recent studies suggest that the absence of RA is important (Trautmann et al. 2008), and this makes 
sense considering that RA appears to have a potent mitotic effect on germ cells (Koshimizu et al. 1995). This conclusion was reached by studies of testes at $13.5 \mathrm{dpc}$ or later, when the resident $X Y$ germ cells are no longer susceptible to the meiosis-inducing effects of RA. It was shown that if $13.5 \mathrm{dpc} X Y$ germ cells in a testis are treated with RA, they upregulate Stra8, but they do not enter meiosis, presumably because the window of opportunity has closed. Instead, they avoid mitotic arrest, the effect working through a phosphatidylinositol 3-kinase signaling mechanism. RA also delayed extinction of FUT4 and remethylation of the genome, suggesting that both mitotic arrest and commitment to the male programme of development had been prevented by the presence of RA (Trautmann et al. 2008). This study therefore suggests that mitotic arrest and male fate selection both follow from the degradation of RA by CYP26B1.

Other studies suggest that it is not simply the absence of meiosis or the absence of RA that leads to mitotic arrest and commitment to the male programme. Early studies demonstrated that germ cells in a fetal ovary do not enter meiosis if the mesonephros is removed, but instead become atretic and disappear (Byskov 1974, O \& Baker 1976). In the light of our understanding of the role of RA produced by the mesonephric duct and tubules, this observation suggests that meiosis fails to occur because the source of RA has been removed. Such XX germ cells do not follow the spermatogenic path, however, suggesting that the male fate choice does not occur by default if meiosis is avoided and therefore that it must be triggered by the testis soma. The observation that $X Y$ germ cells seem to be irreversibly committed by the male pathway by $12.5 \mathrm{dpc}$, while XX germ cells are not committed to the female pathway until $13.5 \mathrm{dpc}$ (McLaren \& Southee 1997, Chuma \& Nakatsuji 2001, Adams \& McLaren 2002) is also in accordance with the theory that $X Y$ germ cells are actively triggered to commit to the male pathway and that it is not simply their failure to enter meiosis that ensures their spermatogenic fate. The testicular factor or factors responsible for positively inducing male germ cell fate have not been identified.

\section{Intrinsic changes in germ cells in the testis environment}

Although we do not know what triggers germ cells in a testis to stop proliferating and commit to spermatogenesis, we do have some knowledge of the molecular changes that occur in germ cells at the time of these events. When XY germ cells in a testis arrest, there are transcriptional changes in some genes encoding cell cycle regulators (Western et al. 2008) as well as an upregulation of transcription of the $\gamma$ isoform of Trp63, a relative of Trp53 (Petre-Lazar et al. 2007). In addition, the P27 protein appears as germ cells enter mitotic quiescence (Western et al. 2008). RB1 is a major cell cycle regulator, and it has recently been demonstrated that the active non-phosphorylated form is present in the fetal testis, whereas only the inactive phosphorylated form is present in the fetal ovary (Western et al. 2008, Spiller et al. 2010). Complete absence of the RB1 protein is associated with a modest delay in mitotic arrest at $14.5 \mathrm{dpc}$, but this is resolved by $16.5 \mathrm{dpc}$ (Spiller et al. 2010). The concomitant upregulation of genes encoding cell cycle inhibitors $C d k n 1 b$ and $C d k n 2 b$ in the $R b 1$-null testes suggests that the testis is able to compensate for the absence of this key cell cycle regulator, and, therefore, that cell cycle arrest in the XY germ cells is likely to involve redundant mechanisms (Spiller et al. 2010).

In addition to stopping their proliferation, $\mathrm{XY}$ germ cells commit to the male programme of development during fetal life. A marker of undifferentiated germ cells, FUT4, is lost. Nanos2, which encodes an RNA-binding protein, seems to lock in spermatogenic fate since in its absence $X Y$ germ cells are still susceptible to the meiosis-inducing effects of RA as late as $15.5 \mathrm{dpc}$ (Suzuki \& Saga 2008). Nanos2 is male-specifically expressed in germ cells beginning at about $13.5 \mathrm{dpc}$ (Tsuda et al. 2003). Nanos2-null XY germ cells undergo mitotic arrest normally at $14.5 \mathrm{dpc}$ but revert to proliferation at $15.5 \mathrm{dpc}$. Moreover, Nanos2-null XY germ cells initiate meiosis at $15.5 \mathrm{dpc}$ before being rapidly removed by apoptosis (Suzuki \& Saga 2008). If apoptosis is prevented (by ablation of the intrinsic pro-apoptotic factor BAX), XY germ cells start to express low levels of Stra 8 at around $14.5 \mathrm{dpc}$ ( 2 days later than Stra8 expression is first observed in the developing ovary; Menke et al. 2003, Suzuki \& Saga 2008). Presumably these meiotic germ cells are responding to increasing levels of RA because Cyp26b1 expression falls at this stage of development (Bowles et al. 2006, Koubova et al. 2006). Overexpression of NANOS2 in XX germ cells in a developing ovary induces markers of male germ cell fate including Dnmt3/ and Tdrd1. DNMT3L seems to act as a general activator of de novo methyltransferases and is involved in progressive remethylation of imprinted sequences in the fetal prospermatogonia from $14.5 \mathrm{dpc}$ (Bourc'his et al. 2001, Bourc'his \& Bestor 2004, Sakai et al. 2004, Kato et al. 2007). TDRD1 is a component of nuage/germinal granules, an evolutionarily conserved cytoplasmic structure in the germ line, in prospermatogonia (Chuma et al. 2003, 2006).

\section{What makes a 'meiosis-competent' germ cell?}

The evidence, overall, suggests that germ cells in the gonad are induced to enter meiosis by RA and also, possibly, inhibited from doing so by one or more as yet unidentified testis-specific factors. However, it is obvious that the mere presence of RA is not sufficient to instruct a cell to embark on meiotic division. RA is widespread in the embryo and is involved in many differentiation events during development (Mark et al. 2009), but only 
germ cells at particular times and in particular locations enter meiosis. Specifically, such germ cells would need to be competent to respond to RA by upregulating Stra8, and they would need to be competent to allow STRA8 to trigger pre-meiotic replication. Presumably, such cells have an intrinsic competence, marked by a set of proteins that are yet to be identified and endowed on them because, first, they are germ cells and, secondly, they have been influenced by extrinsic factors as they traveled through the embryo and entered the environment of the gonad. Extrinsic factors that induce meiotic competence and intrinsic molecular characteristics that define meiotic competence are not yet known, although some clues can be pieced together, as discussed below.

It is likely that epigenetic factors play a major role in the establishment of germ cell competence. A limited range of cell types, including non-germ cells, is able to respond to RA by upregulating Stra8, albeit in artificial culture conditions. Known responders are stem cells, including embryonic stem cells (ESCs), EGCs (Oulad-Abdelghani et al. 1996), and embryonal carcinoma cells (Bouillet et al. 1995), all of which would be expected to be expressing the core pluripotency transcription factors POU5F1, SOX2, and NANOG. It is likely that competence to respond to RA with the expression of Stra8 relates to a particular epigenetic state or chromatin conformation. Stem cells tend to have an 'open' or accessible chromatin conformation, unlike lineage-specific somatic cells (Niwa 2007). The loose open nuclear architecture noted in germ cells shortly after their arrival in the gonad may prove significant in terms of meiotic competence. Intriguingly, these chromatin changes are transient and most obvious at $11.5 \mathrm{dpc}$ (Seki et al. 2005, Hajkova et al. 2008), precisely the time when germ cells would be subject to sex-specific cues from the somatic cells of the developing ovary or testis.

Given this apparent correlation between 'open conformation' pluripotent cell types and the ability to respond to RA with the upregulation of Stra8, it is not surprising that treatment of gonads with the potent histone deactylase inhibitor, trichostatin A (TSA), leads to an increased propensity to express Stra8 (Wang \& Tilly 2010). TSA alters the epigenetic status of a cell directly, increasing histone acetylation and thus making regulatory regions more 'open' or accessible to transcription factors (Toth et al. 2004, Durcova-Hills et al. 2008). More specifically, treatment of gonadal germ cells with TSA has been shown to cause rapid downregulation of Prdm1 (the repressor of an overt pluripotency phenotype in germ cells) and to trigger germ cells to dedifferentiate or reprogramme into EGCs (Ancelin et al. 2006, Durcova-Hills et al. 2008).

So, in general, cells with an 'open' chromatin configuration express Stra8 when subjected to RA. However, most such cells do not subsequently embark on meiosis. During fetal life, meiotic competence appears to be limited to $X X$ and $X Y$ germ cells during the period shortly after their arrival in the gonad. The period of competence begins earlier than is obvious in nature, a fact revealed when the RA-degrading enzyme CYP26B1 is ablated (Bowles et al. 2006). The end of the period of competence is difficult to ascertain based on published work. Some studies have indicated that by $12.5 \mathrm{dpc}$, XY germ cells have already become less able to enter meiosis, presumably because they have already received male fate instructions from somatic cells (McLaren \& Southee 1997, Chuma \& Nakatsuji 2001, Adams \& McLaren 2002). Consistent with this, a more recent work demonstrated that the period of competence must be closed by $13.5 \mathrm{dpc}$ at the latest, because at that time $X Y$ germ cells are able to respond to RA by upregulating Stra8 but are not able to enter meiosis (Trautmann et al. 2008). On the other hand, XY germ cells that upregulate Stra8 around $14.5 \mathrm{dpc}$, in the NANOS2-null; BAX-null background, do enter meiosis (Suzuki \& Saga 2008). Possibly this relatively late entry into meiosis, at $14.5 \mathrm{dpc}$, indicates that under normal circumstances NANOS2 acts to close the period of competence by committing germ cells to the spermatogenic pathway. A very recent study suggests that $X Y$ germ cells remain meiosis-competent up to at least $16.5 \mathrm{dpc}$ (Li et al. 2009). Apparent discrepancies with respect to the end of the period of meiotic competence are likely to reflect the fact that germ cells do not tend to act in concert and processes such as meiosis entry and mitotic arrest occur over several days. Hence, a sub-population of $X Y$ germ cells may be refractory to meiosis induction by $12.5 \mathrm{dpc}$, but a different sub-population may remain competent for several days after $12.5 \mathrm{dpc}$.

Intrinsic factors that underlie meiotic competence are yet to be defined, but some candidates have emerged in recent years. Germ cells normally upregulate $D d x 4$ only after reaching the gonads, and it is not known what triggers this change in expression (Tanaka et al. 2000, Toyooka et al. 2000). DDX4 continues to be expressed throughout embryogenesis in germ cells of the fetal testis and ovary and in spermatocytes, postmeiotic spermatids, and primary oocytes postnatally (Fujiwara et al. 1994, Tanaka et al. 2000, Toyooka et al. 2000). DDX4 is not expressed by pluripotent ES, EG, or inner cell mass (ICM) cells (Fujiwara et al. 1994), but its expression can be induced when mouse EGCs (mEGCs; but not mESCs) are cultured together with fetal gonadal cells (Toyooka et al. 2000). These results suggest that $D d x 4$ expression is induced when germ cells come into contact with gonadal somatic cells, and that ESCs are less competent to respond than EGCs. Interestingly, germ cells in the adrenal not only enter meiosis but also express $D d x 4$ (Runyan et al. 2008). It may be that those germ cells are encountering competence-inducing signals that are the same or similar to signals produced by fetal gonadal cells. It is not likely, however, that expression of $D d x 4$ alone ensures competence to enter meiosis since 


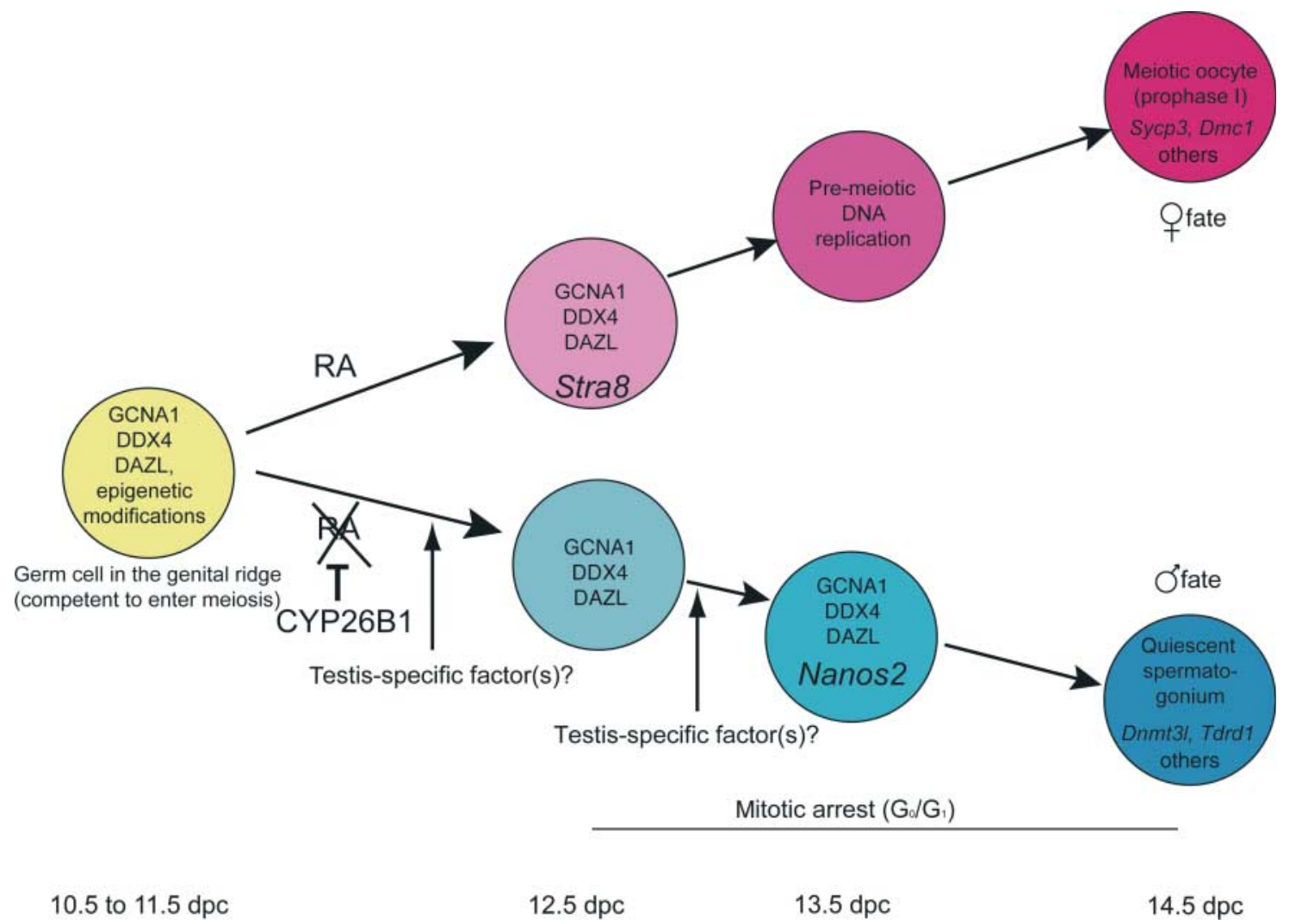

Figure 3 Key intrinsic and extrinsic factors involved in sex determination in murine fetal germ cells. Upon entry into the gonad, germ cells express GCNA1, DDX4, and DAZL, undergo epigenetic modifications, and are presumably competent to enter meiosis. In the presence of RA, produced by somatic cells, germ cells begin to express Stra 8 at about $12.5 \mathrm{dpc}$ and go on to initiate pre-meiotic DNA replication. Ultimately, meiotic marker genes are upregulated, and the germ cells enter prophase I of meiosis thereby committing to the female fate. If RA is degraded by CYP26B1, germ cells do not express Stra8. Mitotic arrest, possibly due to the absence of RA, begins in some germ cells as early as $12.5 \mathrm{dpc}$, although this is not synchronous in the population. A secreted testis-specific factor or factors, as yet unidentified, are likely to signal to the germ cells. At about $13.5 \mathrm{dpc}$, germ cells in the testicular environment begin to express Nanos2. By $14.5 \mathrm{dpc}$, quiescent spermatogonia, in $\mathrm{G}_{0} / \mathrm{G}_{1}$ mitotic arrest, are observed. These spermatogonia express markers of male fate such as Dnmt3/ and Tdrd1. Timing of various processes is approximate.

ablation of $D d x 4$ does not affect normal oogenesis. In the male, DDX4 is not required for entry into meiosis but is required for the continued proliferation and differentiation of germ cells in the testis (Tanaka et al. 2000).

Another possible intrinsic competence factor is the germ cell antigen GCNA1 which, like DDX4, is expressed as germ cells and enter the gonad (Enders \& May 1994). Since this marker is also observed when $8.5 \mathrm{dpc}$ migratory PGCs are placed in culture (Richards et al. 1999), in germ cells located in the adrenal at $14.5 \mathrm{dpc}$, and in SF1 mutant embryos (in which gonad formation is aborted; Wang et al. 1997), it is possible that GCNA1 expression reflects a 'cell-intrinsic programme' of development rather than being an induced event. It is also possible, however, that the necessary inducing signals are present in cell culture media and in the adrenal and peri-gonadal environments. Interestingly, both pre-migratory $(8.5 \mathrm{dpc})$ and post-migratory germ cells $(10.5 \mathrm{dpc})$ expressed GCNA1 when treated in culture with the demethylation agent, 5-azacytidine, or the histone deacetylase inhibitor, trichostatin A
(Maatouk \& Resnick 2003). Possibly GCNA1 expression upon entry into the gonad is related to the significant changes in demethylation and chromatin structure that occur at that time. No GCNA1 KO is available since the gene encoding this antigen is not yet known.

Another gene expressed by XX and XY germ cells shortly after their arrival in the genital ridge is Dazl, which encodes a cytoplasmic RNA-binding protein (Ruggiu et al. 1997, Seligman \& Page 1998, Lin \& Page 2005). Recent results suggest that DAZL may be a 'meiosis competence' factor (Lin et al. 2008). In the Dazl $\mathrm{KO}$, on a $\mathrm{C} 57 \mathrm{BL} / 6$ background, $\mathrm{RA}$ is unable to trigger upregulation of Stra8, increased Sycp3 transcription and translation are not observed, and the double strand breaks characteristic of meiosis do not form. The strict requirement for DAZL in 'meiosis-competent' germ cells is presumably an oversimplification since in the complete absence of DAZL on a non-C57BL/6 background, it allows germ cells in the developing ovary to enter prophase I and progress through to pachytene $(15 \mathrm{dpc})$ before meiosis is arrested and germ cells 
degenerate (Ruggiu et al. 1997, Saunders et al. 2003, Haston et al. 2009). Nonetheless, DAZL is extremely important for the continued development of germ cells once they colonize the gonad. Expression of Dazl seems to be necessary for correct methylation erasure of at least the H19 imprinted locus and for normal levels of expression of $D d x 4$ upon entry into the gonad (Reynolds et al. 2005, Haston et al. 2009). DAZL is known to bind the $3^{\prime}$-UTR of the Sycp3 transcript and positively regulate its translation (Reynolds et al. 2007), so it would seem to make sense that DAZL-negative germ cells would have difficulty in progressing through meiosis. It is possible that DAZL works to affect translation of a number of germ line- and meiosis-specific transcripts. In vitro, DAZL is necessary for the generation of EGCs from germ cells and important for the generation of germ cells from mESCs (Haston et al. 2009). A recent report demonstrates that, when Dazl is overexpressed in mESCs, germ cells can be derived directly, without the need for embryoid body formation (Yu et al. 2009). It is possible, therefore, that DAZL will prove to be a 'gonadal germ cell integrity' factor rather than just a 'meiosis competence' factor.

\section{Conclusions}

Sex determination of the germ cell lineage, in the mammal, occurs in the gonad during fetal development. Germ cells either enter meiosis, and thereby commit to the oogenic pathway, or avoid entry into meiosis, enter a state of quiescence and commit to the spermatogenic pathway. A thorough understanding of germ cell sex determination is important because aberrations in the process underlie infertility and the development of germ cell tumors. Knowledge of the intricacies of the in vivo mechanisms may also aid future attempts to generate gametes in vitro (Feng et al. 2002, Hubner et al. 2003, Toyooka et al. 2003, Geijsen et al. 2004, Nayernia et al. 2006).

The specification of PGCs from a field of pluripotent epiblast cells is dependent on BMP and WNT3 signaling molecules, which seem to induce competence to become the germ cell lineage (Surani et al. 2007, Ohinata et al. 2009, Saitou 2009b). Various intrinsic markers such as PRDM1, PRDM14, DPPA3, POU5F1, NANOG, and SOX2, which correlate with the commitment and potency state of the cells, are known. In addition, germ cells at various stages of the process are characterized by particular epigenetic signatures and chromatin architectures.

The migration, proliferation, and survival of germ cells as they journey through the embryo seem to be dependent on a number of extrinsic factors. The nature of germ cell development is such that that the cells are at different times in different somatic environments - this may ensure the characteristic genetic and epigenetic states observed at various times.
By the time the germ cells enter the gonad they appear to have matured to the point where they are able to respond to an extrinsic cue to enter meiosis (Fig. 3). The extrinsic cue is now firmly established as RA (Baltus et al. 2006, Bowles et al. 2006, Koubova et al. 2006, MacLean et al. 2007, Li \& Clagett-Dame 2009), and the first evidence of its effect is the expression of Stra8 around $12.5 \mathrm{dpc}$ (Menke et al. 2003, Koubova et al. 2006). Proteins that mark germ cells competent to enter meiosis include DDX4, GCNA1, and DAZL, although it is not clear that any of these are critical 'competence factors' since, at least for DDX4 and DAZL, meiosis can occur even in their complete absence (Ruggiu et al. 1997, Tanaka et al. 2000, Saunders et al. 2003, Haston et al. 2009). $X Y$ and $X X$ germ cells are competent to be pushed into meiotic prophase even earlier than $X X$ germ cells do in vivo (Bowles et al. 2006). Presumably XY germ cells remain meiosis-competent until they commit to the male programme at around $12.5 \mathrm{dpc}$ (McLaren \& Southee 1997, Adams \& McLaren 2002).

Commitment to the male programme, as delineated by both mitotic arrest and the expression of male germ cell fate markers such as Nanos2 and Dnmt3l, is likely to be prompted by a male-specific gonadal signaling factor (or factors), as yet unidentified (Fig. 3). A key protein involved in the male fate commitment is the RNAbinding protein NANOS2, but neither the means by which its expression is initiated nor its molecular mode of action are known (Suzuki \& Saga 2008). Mitotic arrest in the developing testis appears to occur only in the absence of RA (Trautmann et al. 2008), but it is likely that it is actually triggered by a male-specific factor or factors, the same or differing from those involved in inducing the expression of male germ cell fate markers.

Although we are making progress in understanding mammalian germ cell sex determination, a great deal remains mysterious. It is not clear to what extent germ cells are pre-programmed to develop and differentiate and to what extent their intrinsic nature at each step reflects the extrinsic signals they have been exposed to. Future studies will focus on key genes Stra8, Dazl, and Nanos 2 and on the identity of postulated extrinsic signaling molecules that are relevant to the process. RNA-binding proteins are likely to important, as they are in other species during the sex determination phase of germ cell development. In addition, the presence and actions of Piwi-interacting RNAs (Aravin \& Bourc'his 2008, Kuramochi-Miyagawa et al. 2008) and miRNAs (Hayashi et al. 2008), in the environment of the developing gonad, are areas of study that are likely to prove illuminating.

\section{Declaration of interest}

The authors declare that there is no conflict of interest that could be perceived as prejudicing the impartiality of this work. 


\section{Funding}

This work was supported by research grants from the Australian Research Council (ARC), and National Health and Medical Research Council of Australia. P Koopman is a Federation Fellow of the ARC.

\section{Acknowledgements}

We thank Antoine Rolland and Cassy Spiller for their critical reading of the manuscript, and anonymous referees for their helpful comments.

\section{References}

Adams IR \& McLaren A 2002 Sexually dimorphic development of mouse primordial germ cells: switching from oogenesis to spermatogenesis. Development 129 1155-1164.

Albrecht KH, Young M, Washburn LL \& Eicher EM 2003 Sry expression level and protein isoform differences play a role in abnormal testis development in C57BL/6) mice carrying certain Sry alleles. Genetics 164 277-288.

Ancelin K, Lange UC, Hajkova P, Schneider R, Bannister AJ, Kouzarides T \& Surani MA 2006 Blimp1 associates with Prmt5 and directs histone arginine methylation in mouse germ cells. Nature Cell Biology 8 623-630.

Anderson R, Fassler R, Georges-Labouesse E, Hynes RO, Bader BL, Kreidberg JA, Schaible K, Heasman J \& Wylie C 1999 Mouse primordial germ cells lacking beta1 integrins enter the germline but fail to migrate normally to the gonads. Development 126 1655-1664.

Anderson EL, Baltus AE, Roepers-Gajadien HL, Hassold TJ, de Rooij DG, van Pelt AM \& Page DC 2008 Stra8 and its inducer, retinoic acid, regulate meiotic initiation in both spermatogenesis and oogenesis in mice. PNAS 105 14976-14980.

Ara T, Nakamura Y, Egawa T, Sugiyama T, Abe K, Kishimoto T, Matsui Y \& Nagasawa T 2003 Impaired colonization of the gonads by primordial germ cells in mice lacking a chemokine, stromal cell-derived factor-1 (SDF-1). PNAS 100 5319-5323.

Aravin AA \& Bourc'his D 2008 Small RNA guides for de novo DNA methylation in mammalian germ cells. Genes and Development 22 970-975.

Baltus AE, Menke DB, Hu YC, Goodheart ML, Carpenter AE, de Rooij DG \& Page DC 2006 In germ cells of mouse embryonic ovaries, the decision to enter meiosis precedes premeiotic DNA replication. Nature Genetics 38 1430-1434.

Bendel-Stenzel MR, Gomperts M, Anderson R, Heasman J \& Wylie C 2000 The role of cadherins during primordial germ cell migration and early gonad formation in the mouse. Mechanisms of Development 91 143-152.

Bendsen E, Byskov AG, Andersen CY \& Westergaard LG 2006 Number of germ cells and somatic cells in human fetal ovaries during the first weeks after sex differentiation. Human Reproduction 21 30-35.

Best D, Sahlender DA, Walther N, Peden AA \& Adams IR 2008 Sdmg1 is a conserved transmembrane protein associated with germ cell sex determination and germline-soma interactions in mice. Development 135 1415-1425.

Bortvin A, Goodheart M, Liao M \& Page DC 2004 Dppa3/Pgc7/stella is a maternal factor and is not required for germ cell specification in mice. BMC Developmental Biology 42.

Bouillet P, Oulad-Abdelghani M, Vicaire S, Garnier JM, Schuhbaur B, Dolle P \& Chambon P 1995 Efficient cloning of cDNAs of retinoic acidresponsive genes in P19 embryonal carcinoma cells and characterization of a novel mouse gene, Stra1 (mouse LERK-2/Eplg2). Developmental Biology 170 420-433.

Bourc'his D \& Bestor TH 2004 Meiotic catastrophe and retrotransposon reactivation in male germ cells lacking Dnmt3L. Nature 431 96-99.

Bourc'his D, Xu GL, Lin CS, Bollman B \& Bestor TH 2001 Dnmt3L and the establishment of maternal genomic imprints. Science 294 2536-2539.
Bowles J \& Koopman P 2007 Retinoic acid, meiosis and germ cell fate in mammals. Development 134 3401-3411.

Bowles J, Knight D, Smith C, Wilhelm D, Richman J, Mamiya S, Yashiro K, Chawengsaksophak K, Wilson MJ, Rossant J et al. 2006 Retinoid signaling determines germ cell fate in mice. Science 312 596-600.

Bullejos M \& Koopman P 2004 Germ cells enter meiosis in a rostro-caudal wave during development of the mouse ovary. Molecular Reproduction and Development 68 422-428.

Bullejos M \& Koopman P 2005 Delayed Sry and Sox9 expression in developing mouse gonads underlies B6-Y(DOM) sex reversal. Developmental Biology 278 473-481.

Byskov AG 1974 Does the rete ovarii act as a trigger for the onset of meiosis? Nature 252 396-397.

Byskov AG 1975 The role of the rete ovarii in meiosis and follicle formation in the cat, mink and ferret. Journal of Reproduction and Fertility $\mathbf{4 5}$ 201-209.

Byskov AG \& Saxen L 1976 Induction of meiosis in fetal mouse testis in vitro. Developmental Biology 52 193-200.

Chuma S \& Nakatsuji N 2001 Autonomous transition into meiosis of mouse fetal germ cells in vitro and its inhibition by gp130-mediated signaling. Developmental Biology 229 468-479.

Chuma S, Hiyoshi M, Yamamoto A, Hosokawa M, Takamune K \& Nakatsuji N 2003 Mouse tudor repeat-1 (MTR-1) is a novel component of chromatoid bodies/nuages in male germ cells and forms a complex with snRNPs. Mechanisms of Development 120 979-990.

Chuma S, Hosokawa M, Kitamura K, Kasai S, Fujioka M, Hiyoshi M, Takamune K, Noce T \& Nakatsuji N 2006 Tdrd1/Mtr-1, a tudor-related gene, is essential for male germ-cell differentiation and nuage/germinal granule formation in mice. PNAS 103 15894-15899.

Combes AN, Wilhelm D, Davidson T, Dejana E, Harley V, Sinclair A \& Koopman P 2009 Endothelial cell migration directs testis cord formation. Developmental Biology 326 112-120.

Cook MS, Coveney D, Batchvarov I, Nadeau JH \& Capel B 2009 BAX-mediated cell death affects early germ cell loss and incidence of testicular teratomas in Dnd1(Ter/Ter) mice. Developmental Biology 328 377-383.

Cool J, Carmona FD, Szucsik JC \& Capel B 2008 Peritubular myoid cells are not the migrating population required for testis cord formation in the $X Y$ gonad. Sexual Development 2 128-133.

Cupp AS, Dufour JM, Kim G, Skinner MK \& Kim KH 1999 Action of retinoids on embryonic and early postnatal testis development. Endocrinology $1402343-2352$.

Di Carlo A \& De Felici M 2000 A role for E-cadherin in mouse primordial germ cell development. Developmental Biology 226 209-219.

Di Carlo AD, Travia G \& De Felici M 2000 The meiotic specific synaptonemal complex protein SCP3 is expressed by female and male primordial germ cells of the mouse embryo. International Journal of Developmental Biology 44 241-244.

Ding J, Jiang D, Kurczy M, Nalepka J, Dudley B, Merkel El, Porter FD, Ewing AG, Winograd N, Burgess J et al. 2008 Inhibition of HMG CoA reductase reveals an unexpected role for cholesterol during PGC migration in the mouse. BMC Developmental Biology 8120.

Dolle P, Ruberte E, Leroy P, Morriss-Kay G \& Chambon P 1990 Retinoic acid receptors and cellular retinoid binding proteins. I. A systematic study of their differential pattern of transcription during mouse organogenesis. Development 110 1133-1151.

Donovan PJ, Stott D, Cairns LA, Heasman J \& Wylie CC 1986 Migratory and postmigratory mouse primordial germ cells behave differently in culture. Cell 44 831-838.

Dudley BM, Runyan C, Takeuchi Y, Schaible K \& Molyneaux K 2007 BMP signaling regulates PGC numbers and motility in organ culture. Mechanisms of Development 124 68-77.

Duester G 2008 Retinoic acid synthesis and signaling during early organogenesis. Cell 134 921-931.

Durcova-Hills G, Tang F, Doody G, Tooze R \& Surani MA 2008 Reprogramming primordial germ cells into pluripotent stem cells. PLoS ONE 3 e3531.

Eicher EM, Washburn LL, Whitney JB III \& Morrow KE 1982 Mus poschiavinus $\mathrm{Y}$ chromosome in the $\mathrm{C} 57 \mathrm{BL} / 6 \mathrm{~J}$ murine genome causes sex reversal. Science 217 535-537. 
Enders GC \& May JJ II 1994 Developmentally regulated expression of a mouse germ cell nuclear antigen examined from embryonic day 11 to adult in male and female mice. Developmental Biology 163 331-340.

Evans EP, Ford CE \& Lyon MF 1977 Direct evidence of the capacity of the XY germ cell in the mouse to become an oocyte. Nature 267 430-431.

Farini D, Scaldaferri ML, Iona S, La Sala G \& De Felici M 2005 Growth factors sustain primordial germ cell survival, proliferation and entering into meiosis in the absence of somatic cells. Developmental Biology 285 49-56.

Farini D, La Sala G, Tedesco M \& De Felici M 2007 Chemoattractant action and molecular signaling pathways of kit ligand on mouse primordial germ cells. Developmental Biology 306 572-583.

Feng LX, Chen Y, Dettin L, Pera RA, Herr JC, Goldberg E \& Dym M 2002 Generation and in vitro differentiation of a spermatogonial cell line. Science 297 392-395.

Francavilla S \& Zamboni L 1985 Differentiation of mouse ectopic germinal cells in intra- and perigonadal locations. Journal of Experimental Zoology 233 101-109.

Fuchs E \& Green H 1981 Regulation of terminal differentiation of cultured human keratinocytes by vitamin A. Cell 25 617-625.

Fujiwara Y, Komiya T, Kawabata H, Sato M, Fujimoto H, Furusawa M \& Noce T 1994 Isolation of a DEAD-family protein gene that encodes a murine homolog of Drosophila vasa and its specific expression in germ cell lineage. PNAS 91 12258-12262.

Geijsen N, Horoschak M, Kim K, Gribnau J, Eggan K \& Daley GQ 2004 Derivation of embryonic germ cells and male gametes from embryonic stem cells. Nature $\mathbf{4 2 7} 148-154$

Ginsburg M, Snow MH \& McLaren A 1990 Primordial germ cells in the mouse embryo during gastrulation. Development 110 521-528.

Hajkova P, Erhardt S, Lane N, Haaf T, El-Maarri O, Reik W, Walter J \& Surani MA 2002 Epigenetic reprogramming in mouse primordial germ cells. Mechanisms of Development 117 15-23.

Hajkova P, Ancelin K, Waldmann T, Lacoste N, Lange UC, Cesari F, Lee C, Almouzni G, Schneider R \& Surani MA 2008 Chromatin dynamics during epigenetic reprogramming in the mouse germ line. Nature $\mathbf{4 5 2}$ 877-881.

Haselbeck RJ \& Duester G 1998 ADH1 and ADH4 alcohol/retinol dehydrogenases in the developing adrenal blastema provide evidence for embryonic retinoid endocrine function. Developmental Dynamics 213 114-120.

Haselbeck RJ, Ang HL, Deltour L \& Duester G 1997 Retinoic acid and alcohol/retinol dehydrogenase in the mouse adrenal gland: a potential endocrine source of retinoic acid during development. Endocrinology 138 3035-3041.

Haston KM, Tung JY \& Reijo Pera RA 2009 Dazl functions in maintenance of pluripotency and genetic and epigenetic programs of differentiation in mouse primordial germ cells in vivo and in vitro. PLOS ONE 4 e5654.

Hayashi K, de Sousa Lopes SM \& Surani MA 2007 Germ cell specification in mice. Science 316 394-396.

Hayashi K, Chuva de Sousa Lopes SM, Kaneda M, Tang F, Hajkova P, Lao K, O'Carroll D, Das PP, Tarakhovsky A, Miska EA et al. 2008 MicroRNA biogenesis is required for mouse primordial germ cell development and spermatogenesis. PLoS ONE 3 e1738.

Hilscher B, Hilscher W, Bulthoff-Ohnolz B, Kramer U, Birke A, Pelzer H \& Gauss G 1974 Kinetics of gametogenesis. I. Comparative histological and autoradiographic studies of oocytes and transitional prospermatogonia during oogenesis and prespermatogenesis. Cell and Tissue Research 154 443-470.

Hubner K, Fuhrmann G, Christenson LK, Kehler J, Reinbold R, De La Fuente R, Wood J, Strauss JF III, Boiani M \& Scholer HR 2003 Derivation of oocytes from mouse embryonic stem cells. Science $\mathbf{3 0 0}$ 1251-1256.

Kato Y, Kaneda M, Hata K, Kumaki K, Hisano M, Kohara Y, Okano M, Li E, Nozaki M \& Sasaki H 2007 Role of the Dnmt3 family in de novo methylation of imprinted and repetitive sequences during male germ cell development in the mouse. Human Molecular Genetics 16 2272-2280.

Kedde M, Strasser MJ, Boldajipour B, Oude Vrielink JA, Slanchev K, le Sage C, Nagel R, Voorhoeve PM, van Duijse J, Orom UA et al. 2007 RNA-binding protein Dnd1 inhibits microRNA access to target mRNA. Cell 131 1273-1286.

Koopman P, Gubbay J, Vivian N, Goodfellow P \& Lovell-Badge R 1991 Male development of chromosomally female mice transgenic for Sry. Nature 351 117-121.
Koshimizu U, Watanabe M \& Nakatsuji N 1995 Retinoic acid is a potent growth activator of mouse primordial germ cells in vitro. Developmental Biology 168 683-685.

Koubova J, Menke DB, Zhou Q, Capel B, Griswold MD \& Page DC 2006 Retinoic acid regulates sex-specific timing of meiotic initiation in mice. PNAS 103 2474-2479.

Kuramochi-Miyagawa S, Watanabe T, Gotoh K, Totoki Y, Toyoda A, Ikawa M, Asada N, Kojima K, Yamaguchi Y, ljiri TW et al. 2008 DNA methylation of retrotransposon genes is regulated by Piwi family members MILI and MIWI2 in murine fetal testes. Genes and Development 22 908-917.

Labosky PA, Barlow DP \& Hogan BL 1994 Mouse embryonic germ (EG) cell lines: transmission through the germline and differences in the methylation imprint of insulin-like growth factor 2 receptor (Igf2r) gene compared with embryonic stem (ES) cell lines. Development 120 3197-3204.

Lange UC, Adams DJ, Lee C, Barton S, Schneider R, Bradley A \& Surani MA 2008 Normal germ line establishment in mice carrying a deletion of the Ifitm/Fragilis gene family cluster. Molecular and Cellular Biology 28 4688-4696.

Lawson KA \& Hage WJ 1994 Clonal analysis of the origin of primordial germ cells in the mouse. Ciba Foundation Symposia 182 68-84 (discussion 84-91).

Lawson KA, Dunn NR, Roelen BA, Zeinstra LM, Davis AM, Wright CV, Korving JP \& Hogan BL 1999 Bmp4 is required for the generation of primordial germ cells in the mouse embryo. Genes and Development 13 424-436.

Lee J, Inoue K, Ono R, Ogonuki N, Kohda T, Kaneko-Ishino T, Ogura A \& Ishino F 2002 Erasing genomic imprinting memory in mouse clone embryos produced from day 11.5 primordial germ cells. Development 129 1807-1817.

Li H \& Clagett-Dame M 2009 Vitamin A deficiency blocks the initiation of meiosis of germ cells in the developing rat ovary in vivo. Biology of Reproduction 81 996-1001.

Li H, Maclean G, Cameron D, Clagett-Dame M \& Petkovich M 2009 Cyp26b1 expression in murine sertoli cells is required to maintain male germ cells in an undifferentiated state during embryogenesis. PLOS ONE 4 e7501.

Lin Y \& Page DC 2005 Dazl deficiency leads to embryonic arrest of germ cell development in XY C57BL/6 mice. Developmental Biology 288 309-316.

Lin Y, Gill ME, Koubova J \& Page DC 2008 Germ cell-intrinsic and -extrinsic factors govern meiotic initiation in mouse embryos. Science $\mathbf{3 2 2}$ 1685-1687.

Maatouk DM \& Resnick JL 2003 Continuing primordial germ cell differentiation in the mouse embryo is a cell-intrinsic program sensitive to DNA methylation. Developmental Biology 258 201-208.

MacGregor GR, Zambrowicz BP \& Soriano P 1995 Tissue non-specific alkaline phosphatase is expressed in both embryonic and extraembryonic lineages during mouse embryogenesis but is not required for migration of primordial germ cells. Development 121 1487-1496.

MacLean G, Li H, Metzger D, Chambon P \& Petkovich M 2007 Apoptotic extinction of germ cells in testes of Cyp26b1 knockout mice. Endocrinology 148 4560-4567.

Mahakali Zama A, Hudson FP III \& Bedell MA 2005 Analysis of hypomorphic KitISI mutants suggests different requirements for KITL in proliferation and migration of mouse primordial germ cells. Biology of Reproduction 73 639-647.

Malpel S, Mendelsohn C \& Cardoso WV 2000 Regulation of retinoic acid signaling during lung morphogenesis. Development 127 3057-3067.

Mark M, Jacobs H, Oulad-Abdelghani M, Dennefeld C, Feret B, Vernet N, Codreanu CA, Chambon P \& Ghyselinck NB 2008 STRA8-deficient spermatocytes initiate, but fail to complete, meiosis and undergo premature chromosome condensation. Journal of Cell Science $\mathbf{1 2 1}$ 3233-3242.

Mark M, Ghyselinck NB \& Chambon P 2009 Function of retinoic acid receptors during embryonic development. Nuclear Receptor Signaling $7 \mathrm{e} 002$.

McLaren A 1975 Sex chimaerism and germ cell distribution in a series of chimaeric mice. Journal of Embryology and Experimental Morphology 33 205-216. 
McLaren A 1981 The fate of germ cells in the testis of fetal sex-reversed mice. Journal of Reproduction and Fertility 61 461-467.

McLaren A 1984 Meiosis and differentiation of mouse germ cells. Symposia of the Society for Experimental Biology 38 7-23.

McLaren A 2003 Primordial germ cells in the mouse. Developmental Biology 262 1-15.

McLaren A \& Southee D 1997 Entry of mouse embryonic germ cells into meiosis. Developmental Biology 187 107-113.

Menke DB \& Page DC 2002 Sexually dimorphic gene expression in the developing mouse gonad. Gene Expression Patterns 2 359-367.

Menke DB, Koubova J \& Page DC 2003 Sexual differentiation of germ cells in XX mouse gonads occurs in an anterior-to-posterior wave. Developmental Biology 262 303-312.

Molyneaux KA, Stallock J, Schaible K \& Wylie C 2001 Time-lapse analysis of living mouse germ cell migration. Developmental Biology 240 488-498.

Molyneaux KA, Zinszner H, Kunwar PS, Schaible K, Stebler J, Sunshine MJ, O'Brien W, Raz E, Littman D, Wylie C et al. 2003 The chemokine SDF1/CXCL12 and its receptor CXCR4 regulate mouse germ cell migration and survival. Development 130 4279-4286.

Molyneaux KA, Wang Y, Schaible K \& Wylie C 2004 Transcriptional profiling identifies genes differentially expressed during and after migration in murine primordial germ cells. Gene Expression Patterns 4 167-181.

Monk M \& McLaren A 1981 X-chromosome activity in foetal germ cells of the mouse. Journal of Embryology and Experimental Morphology 63 75-84.

Monk M, Boubelik M \& Lehnert S 1987 Temporal and regional changes in DNA methylation in the embryonic, extraembryonic and germ cell lineages during mouse embryo development. Development 99 371-382.

Morita Y \& Tilly JL 1999 Segregation of retinoic acid effects on fetal ovarian germ cell mitosis versus apoptosis by requirement for new macromolecular synthesis. Endocrinology 140 2696-2703.

Nayernia K, Nolte J, Michelmann HW, Lee JH, Rathsack K, Drusenheimer N, Dev A, Wulf G, Ehrmann IE, Elliott DJ et al. 2006 In vitro-differentiated embryonic stem cells give rise to male gametes that can generate offspring mice. Developmental Cell 11 125-132.

Niwa H 2007 Open conformation chromatin and pluripotency. Genes and Development 21 2671-2676.

O W-S \& Baker TG 1976 Initiation and control of meiosis in hamster gonads in vitro. Journal of Reproduction and Fertility 48 399-401.

Ohinata Y, Payer B, O'Carroll D, Ancelin K, Ono Y, Sano M, Barton SC, Obukhanych T, Nussenzweig M, Tarakhovsky A et al. 2005 Blimp1 is a critical determinant of the germ cell lineage in mice. Nature $\mathbf{4 3 6}$ 207-213.

Ohinata Y, Ohta H, Shigeta M, Yamanaka K, Wakayama T \& Saitou M 2009 A signaling principle for the specification of the germ cell lineage in mice. Cell 137 571-584.

Ohkubo Y, Shirayoshi Y \& Nakatsuji N 1996 Autonomous regulation of proliferation and growth arrest in mouse primordial germ cells studied by mixed and clonal cultures. Experimental Cell Research 222 291-297.

Oulad-Abdelghani M, Bouillet P, Decimo D, Gansmuller A, Heyberger S, Dolle P, Bronner S, Lutz Y \& Chambon P 1996 Characterization of a premeiotic germ cell-specific cytoplasmic protein encoded by Stra8, a novel retinoic acid-responsive gene. Journal of Cell Biology 135 469-477.

Palmer SJ \& Burgoyne PS 1991 In situ analysis of fetal, prepuberal and adult $X X-X Y$ chimaeric mouse testes: Sertoli cells are predominantly, but not exclusively, XY. Development 112 265-268.

Petre-Lazar B, Livera G, Moreno SG, Trautmann E, Duquenne C, Hanoux V, Habert R \& Coffigny H 2007 The role of p63 in germ cell apoptosis in the developing testis. Journal of Cellular Physiology 210 87-98.

Reynolds N, Collier B, Maratou K, Bingham V, Speed RM, Taggart M, Semple CA, Gray NK \& Cooke HJ 2005 Dazl binds in vivo to specific transcripts and can regulate the pre-meiotic translation of Mvh in germ cells. Human Molecular Genetics 14 3899-3909.

Reynolds N, Collier B, Bingham V, Gray NK \& Cooke HJ 2007 Translation of the synaptonemal complex component Sycp3 is enhanced in vivo by the germ cell specific regulator Dazl. RNA 13 974-981.

Richards AJ, Enders GC \& Resnick JL 1999 Differentiation of murine premigratory primordial germ cells in culture. Biology of Reproduction 61 1146-1151.
Richardson BE \& Lehmann R 2010 Mechanisms guiding primordial germ cell migration: strategies from different organisms. Nature Reviews. Molecular Cell Biology 11 37-49.

Rossant J, Zirngibl R, Cado D, Shago M \& Giguere V 1991 Expression of a retinoic acid response element-hsplacZ transgene defines specific domains of transcriptional activity during mouse embryogenesis. Genes and Development 5 1333-1344.

Ruggiu M, Speed R, Taggart M, McKay SJ, Kilanowski F, Saunders P, Dorin J \& Cooke HJ 1997 The mouse Dazla gene encodes a cytoplasmic protein essential for gametogenesis. Nature 389 73-77.

Runyan C, Schaible K, Molyneaux K, Wang Z, Levin L \& Wylie C 2006 Steel factor controls midline cell death of primordial germ cells and is essential for their normal proliferation and migration. Development 133 4861-4869.

Runyan C, Gu Y, Shoemaker A, Looijenga L \& Wylie C 2008 The distribution and behavior of extragonadal primordial germ cells in Bax mutant mice suggest a novel origin for sacrococcygeal germ cell tumors. International Journal of Developmental Biology 52 333-344.

Saitou M 2009a Germ cell specification in mice. Current Opinion in Genetics \& Development 19 386-395.

Saitou M $2009 b$ Specification of the germ cell lineage in mice. Frontiers in Bioscience 14 1068-1087.

Saitou M, Barton SC \& Surani MA 2002 A molecular programme for the specification of germ cell fate in mice. Nature 418 293-300.

Saitou M, Payer B, O'Carroll D, Ohinata Y \& Surani MA 2005 Blimp1 and the emergence of the germ line during development in the mouse. Cell Cycle 4 1736-1740.

Sakai Y, Suetake I, Shinozaki F, Yamashina S \& Tajima S 2004 Co-expression of de novo DNA methyltransferases Dnmt3a2 and Dnmt3L in gonocytes of mouse embryos. Gene Expression Patterns 5 231-237.

Sato S, Yoshimizu T, Sato E \& Matsui Y 2003 Erasure of methylation imprinting of Igf2r during mouse primordial germ-cell development. Molecular Reproduction and Development 65 41-50.

Saunders PT, Turner JM, Ruggiu M, Taggart M, Burgoyne PS, Elliott D \& Cooke HJ 2003 Absence of mDazl produces a final block on germ cell development at meiosis. Reproduction 126 589-597.

Seki Y, Hayashi K, Itoh K, Mizugaki M, Saitou M \& Matsui Y 2005 Extensive and orderly reprogramming of genome-wide chromatin modifications associated with specification and early development of germ cells in mice. Developmental Biology 278 440-458.

Seligman J \& Page DC 1998 The Dazh gene is expressed in male and female embryonic gonads before germ cell sex differentiation. Biochemical and Biophysical Research Communications 245 878-882.

Smith CA, Roeszler KN, Bowles J, Koopman P \& Sinclair AH 2008 Onset of meiosis in the chicken embryo; evidence of a role for retinoic acid. $B M C$ Developmental Biology 885.

Soprano DR, Teets BW \& Soprano KJ 2007 Role of retinoic acid in the differentiation of embryonal carcinoma and embryonic stem cells. Vitamins and Hormones 75 69-95.

de Sousa Lopes SM, Roelen BA, Monteiro RM, Emmens R, Lin HY, Li E, Lawson KA \& Mummery CL 2004 BMP signaling mediated by ALK2 in the visceral endoderm is necessary for the generation of primordial germ cells in the mouse embryo. Genes and Development 18 1838-1849.

Speed RM 1982 Meiosis in the foetal mouse ovary. I. An analysis at the light microscope level using surface-spreading. Chromosoma 85 427-437.

Spiller CM, Wilhelm D \& Koopman P 2010 Retinoblastoma 1 protein modulates $X Y$ germ cell entry into $\mathrm{G}_{1} / \mathrm{G}_{0}$ arrest during fetal development in mice. Biology of Reproduction 82 433-443.

Stebler J, Spieler D, Slanchev K, Molyneaux KA, Richter U, Cojocaru V, Tarabykin V, Wylie C, Kessel M \& Raz E 2004 Primordial germ cell migration in the chick and mouse embryo: the role of the chemokine SDF-1/CXCL12. Developmental Biology 272 351-361.

Stevens LC 1973 A new inbred subline of mice (129/terSv) with a high incidence of spontaneous congenital testicular teratomas. Journal of the National Cancer Institute 50 235-242.

Sugimoto M \& Abe E 2007 X chromosome reactivation initiates in nascent primordial germ cells in mice. PLoS Genetics 3 e116.

Surani MA, Hayashi K \& Hajkova P 2007 Genetic and epigenetic regulators of pluripotency. Cell 128 747-762.

Suzuki A \& Saga Y 2008 Nanos2 suppresses meiosis and promotes male germ cell differentiation. Genes and Development 22 430-435. 
Szabo PE \& Mann JR 1995 Biallelic expression of imprinted genes in the mouse germ line: implications for erasure, establishment, and mechanisms of genomic imprinting. Genes and Development 9 1857-1868.

Tada T, Tada M, Hilton K, Barton SC, Sado T, Takagi N \& Surani MA 1998 Epigenotype switching of imprintable loci in embryonic germ cells. Development Genes and Evolution 207 551-561.

Takeuchi Y, Molyneaux K, Runyan C, Schaible K \& Wylie C 2005 The roles of FGF signaling in germ cell migration in the mouse. Development 132 5399-5409.

Tam PP \& Zhou SX 1996 The allocation of epiblast cells to ectodermal and germ-line lineages is influenced by the position of the cells in the gastrulating mouse embryo. Developmental Biology 178 124-132.

Tam PP, Zhou SX \& Tan SS 1994 X-chromosome activity of the mouse primordial germ cells revealed by the expression of an X-linked lacZ transgene. Development 120 2925-2932.

Tanaka SS, Toyooka Y, Akasu R, Katoh-Fukui Y, Nakahara Y, Suzuki R, Yokoyama M \& Noce T 2000 The mouse homolog of Drosophila vasa is required for the development of male germ cells. Genes and Development 14 841-853.

Tanaka SS, Yamaguchi YL, Tsoi B, Lickert H \& Tam PP 2005 IFITM/Mil/fragilis family proteins IFITM1 and IFITM3 play distinct roles in mouse primordial germ cell homing and repulsion. Developmental Cell 9 745-756.

Tedesco M, La Sala G, Barbagallo F, De Felici M \& Farini D 2009 Stimulated by retinoic acid gene 8 (STRA8) shuttles between nucleus and cytoplasm and displays transcriptional activity. Journal of Biological Chemistry 284 35781-35793.

Thorpe JL, Doitsidou M, Ho SY, Raz E \& Farber SA 2004 Germ cell migration in zebrafish is dependent on $\mathrm{HMGCoA}$ reductase activity and prenylation. Developmental Cell 6 295-302.

Toth KF, Knoch TA, Wachsmuth M, Frank-Stohr M, Stohr M, Bacher CP, Muller G \& Rippe K 2004 Trichostatin A-induced histone acetylation causes decondensation of interphase chromatin. Journal of Cell Science 117 4277-4287.

Toyooka Y, Tsunekawa N, Takahashi Y, Matsui Y, Satoh M \& Noce T 2000 Expression and intracellular localization of mouse vasa-homologue protein during germ cell development. Mechanisms of Development 93 139-149.

Toyooka Y, Tsunekawa N, Akasu R \& Noce T 2003 Embryonic stem cells can form germ cells. PNAS 100 11457-11462.

Trautmann E, Guerquin MJ, Duquenne C, Lahaye JB, Habert R \& Livera G 2008 Retinoic acid prevents germ cell mitotic arrest in mouse fetal testes. Cell Cycle 7 656-664.

Tsuda M, Sasaoka Y, Kiso M, Abe K, Haraguchi S, Kobayashi S \& Saga Y 2003 Conserved role of nanos proteins in germ cell development. Science 301 1239-1241.

Upadhyay S \& Zamboni L 1982 Ectopic germ cells: natural model for the study of germ cell sexual differentiation. PNAS 79 6584-6588.

Vigier B, Watrin F, Magre S, Tran D \& Josso N 1987 Purified bovine AMH induces a characteristic freemartin effect in fetal rat prospective ovaries exposed to it in vitro. Development $10043-55$.

Vincent SD, Dunn NR, Sciammas R, Shapiro-Shalef M, Davis MM, Calame K, Bikoff EK \& Robertson EJ 2005 The zinc finger transcriptional repressor Blimp1/Prdm1 is dispensable for early axis formation but is required for specification of primordial germ cells in the mouse. Development 132 1315-1325.

Wallacides A, Chesnel A, Chardard D, Flament S \& Dumond H 2009 Evidence for a conserved role of retinoic acid in urodele amphibian meiosis onset. Developmental Dynamics 238 1389-1398.

Wang N \& Tilly JL 2010 Epigenetic status determines germ cell meiotic commitment in embryonic and postnatal mammalian gonads. Cell Cycle 9 339-349.
Wang D, Ikeda Y, Parker KL \& Enders GC 1997 Germ cell nuclear antigen (GCNA1) expression does not require a gonadal environment or steroidogenic factor 1: examination of GCNA1 in ectopic germ cells and in Ftz-F1 null mice. Molecular Reproduction and Development 48 154-158.

Washburn LL, Albrecht KH \& Eicher EM 2001 C57BL/6J-T-associated sex reversal in mice is caused by reduced expression of a Mus domesticus Sry allele. Genetics 158 1675-1681.

Weidinger G, Stebler J, Slanchev K, Dumstrei K, Wise C, Lovell-Badge R, Thisse C, Thisse B \& Raz E 2003 Dead end, a novel vertebrate germ plasm component, is required for zebrafish primordial germ cell migration and survival. Current Biology 13 1429-1434.

West JA, Viswanathan SR, Yabuuchi A, Cunniff K, Takeuchi A, Park IH, Sero JE, Zhu H, Perez-Atayde A, Frazier AL et al. 2009 A role for Lin28 in primordial germ-cell development and germ-cell malignancy. Nature 460 909-913.

Western PS, Miles DC, van den Bergen JA, Burton M \& Sinclair AH 2008 Dynamic regulation of mitotic arrest in fetal male germ cells. Stem Cells 26 339-347.

Wilhelm D, Washburn LL, Truong V, Fellous M, Eicher EM \& Koopman P 2009 Antagonism of the testis- and ovary-determining pathways during ovotestis development in mice. Mechanisms of Development 126 324-336.

Wylie C 1999 Germ cells. Cell 96 165-174.

Yabuta Y, Kurimoto K, Ohinata Y, Seki Y \& Saitou M 2006 Gene expression dynamics during germline specification in mice identified by quantitative single-cell gene expression profiling. Biology of Reproduction $\mathbf{7 5}$ 705-716

Yamaji M, Seki Y, Kurimoto K, Yabuta Y, Yuasa M, Shigeta M, Yamanaka K, Ohinata Y \& Saitou M 2008 Critical function of Prdm14 for the establishment of the germ cell lineage in mice. Nature Genetics $\mathbf{4 0}$ 1016-1022.

Yao HH, DiNapoli L \& Capel B 2003 Meiotic germ cells antagonize mesonephric cell migration and testis cord formation in mouse gonads. Development 130 5895-5902.

Yeom YI, Fuhrmann G, Ovitt CE, Brehm A, Ohbo K, Gross M, Hubner K \& Scholer HR 1996 Germline regulatory element of Oct-4 specific for the totipotent cycle of embryonal cells. Development 122 881-894.

Ying Y \& Zhao GQ 2001 Cooperation of endoderm-derived BMP2 and extraembryonic ectoderm-derived BMP4 in primordial germ cell generation in the mouse. Developmental Biology 232 484-492.

Ying Y, Liu XM, Marble A, Lawson KA \& Zhao GQ 2000 Requirement of Bmp8b for the generation of primordial germ cells in the mouse. Molecular Endocrinology 14 1053-1063.

Youngren KK, Coveney D, Peng X, Bhattacharya C, Schmidt LS, Nickerson ML, Lamb BT, Deng JM, Behringer RR, Capel B et al. 2005 The Ter mutation in the dead end gene causes germ cell loss and testicular germ cell tumours. Nature 435 360-364.

Yu Z, Ji P, Cao J, Zhu S, Li Y, Zheng L, Chen X \& Feng L 2009 Dazl promotes germ cell differentiation from embryonic stem cells. Journal of Molecular Cell Biology 1 93-103.

Zamboni L \& Upadhyay S 1983 Germ cell differentiation in mouse adrenal glands. Journal of Experimental Zoology 228 173-193.

Received 5 February 2010

First decision 15 March 2010

Accepted 15 April 2010 